\title{
Bis(diphenylphosphino)acetylene as bifunctional ligand in cycloplatinated complexes: Synthesis, characterization, crystal structures and mechanism of MeI oxidative addition
}

\author{
S. Masoud Nabavizadeh ${ }^{\mathrm{a}, *}$, Hajar Sepehrpour ${ }^{\mathrm{a}}$, Reza Kia ${ }^{\mathrm{b}, \mathrm{c}}$, Arnold L. Rheingold ${ }^{\mathrm{d}}$ \\ a Department of Chemistry, College of Sciences, Shiraz University, Shiraz 71454, Iran \\ ${ }^{\mathrm{b}}$ Department of Chemistry, Science and Research Branch, Islamic Azad University, Tehran, Iran \\ ${ }^{\mathrm{c}}$ Deutsches Elektronen-Synchrotron (DESY), Division Structural Dynamics of (Bio)chemical Systems, Photon Science at DESY, Notkestr, \\ 85, 22607 Hamburg, Germany \\ ${ }^{\mathrm{d}}$ Department of Chemistry and Biochemistry, University of California at San Diego, La Jolla, CA 92093, USA
}

\section{A R T I C L E I N F O}

\section{Article history:}

Received 30 May 2013

Received in revised form

9 July 2013

Accepted 10 July 2013

Dedicated to Prof. Mehdi Rashidi, a great teacher, in friendship and appreciation.

\section{Keywords:}

Organoplatinum

Kinetic and mechanism

Crystal structure

\begin{abstract}
A B S T R A C T
Binuclear cycloplatinated(II) complexes with general formula of $\left[\mathrm{Pt}_{2} \mathrm{Me}_{2}(\mathrm{CN})_{2}(\mu\right.$-dppac)], $(\mathbf{1}, \mathrm{CN}=$ deprotonated 2-phenylpyridine (ppy); $2, \mathrm{CN}=$ deprotonated benzo\{h\}quinoline (bhq)) in which dppac $=1,1^{\prime}$-bis(diphenylphosphino)acetylene, are synthesized by the reaction of $\left[\mathrm{PtMe}\left(\mathrm{SMe}_{2}\right)(\mathrm{CN})\right]$ with 0.5 equiv of dppac at room temperature. The complexes are fully characterized using multinuclear $\left({ }^{1} \mathrm{H},{ }^{31} \mathrm{P}\right.$ and $\left.{ }^{195} \mathrm{Pt}\right)$ NMR spectroscopy and complex $\mathbf{2}$ is further identified by single crystal X-ray structure determination. Kinetics of the reaction of complexes $\mathbf{1}$ and $\mathbf{2}$ with MeI are investigated in $\mathrm{CHCl}_{3}$ and based on the UV-vis and ${ }^{31} \mathrm{P}$ NMR data, a mechanism involving a double Mel oxidative addition is suggested. The classical $\mathrm{S}_{\mathrm{N}} 2$ mechanism is proposed for both steps and the involved intermediates are suggested. Although MeI in each step was trans oxidatively added to one of the platinum(II) centers, further trans to cis isomerizations of methyl and iodide ligands were also identified. The rates are almost four times slower in the second step as compared to the first step due to the electronic effects transmitted through the dppac ligand. Reaction rates concerning complex 2, having bhq ligand, are almost 1.3 times slower than those involving the related ppy complex $\mathbf{1}$. This is attributed to the stronger donor ability of the ppy ligand, as compared to that bhq ligand and is in agreement with the values of ${ }^{1} \mathrm{JPtP}$ observed in the ${ }^{31} \mathrm{P}$ NMR spectra of the complexes $\mathbf{1}$ and $\mathbf{2}$. The structure of the $\mathrm{Pt}(\mathrm{IV})-\mathrm{Pt}(\mathrm{IV})$ dimeric complex $\left[\mathrm{Pt}_{2} \mathrm{I}_{2} \mathrm{Me}_{4}(\mathrm{ppy})_{2}(\mu\right.$-dppac)], 3, produced by oxidative addition of complex $\mathbf{1}$ to MeI, is also determined using X-ray diffraction which is the first X-ray structural determination of a diplatinum complex containing two Pt(IV) centers bridged by one dppac ligand.
\end{abstract}

(c) 2013 Elsevier B.V. All rights reserved.

\section{Introduction}

Binuclear transition metal complexes that show ligand-mediated metal-to-metal electronic communications are extensively investigated due to their potential application to molecular-scale electronics and devices [1,2]. Additionally, these complexes are attractive because they provide interesting mixed-valence species that are regarded as prototypes for molecular switches and wires [1-9]. The binuclear complexes containing bridging ligands have

\footnotetext{
* Corresponding author. Tel.: +98 711613 7110; fax: +98 7116460788 .

E-mail addresses: nabavi@chem.susc.ac.ir, nabavizadeh@yahoo.com (S.M. Nabavizadeh).
}

also received much attention due to their potential applications in catalysis, molecular recognition and photoactive devices [10-12]. A key to synthesize the related two-centered metal-based material is the selection of bridging ligands capable of mediating electronic communications. The spacers used are, in most cases, either C-donor or N-/O-donor ligands connected by $s p$ or $s p^{2}$ carbon chains [13-20]. Like the conjugated $\mathrm{N}$ - or $\mathrm{C}$-donor ligands, the rodlike P-donor spacers also display some characteristics such as photostability, conjugation and rigidity. These P-donor ligands have molecular orbitals with suitable energies to overlap with those of the attached metal centers. The capacity of bis(diphenylphosphino)acetylene $\left(\mathrm{Ph}_{2} \mathrm{PC} \equiv \mathrm{CPPh}_{2}\right.$, abbreviated as dppac) to act as a bifunctional ligand to transition metals has been examined [21-28]. This ligand has a 
linear geometry with two terminal phosphine moieties and one acetylene moiety able to coordinate to metal ions $[29,30]$. The dominant coordination modes, which leave the ligand intact, are end-on terminal [31,32] and end-on bridging [33-36] coordination through the phosphorus atoms.

On the other hand, transition metal cyclometalated complexes, in particular those involving platinum and 2-phenylpyridyine are of interest due to their potential applications as chemosensors [37], photocatalysts [38] and luminescence [39-50]. Square planar cyclometalated platinum complexes have also been used as "building blocks" for complex systems such as self-assembly[51] and dendrimers [52,53].

We have recently studied the synthesis and reactivity of some cyclometalated organoplatinum complexes aiming to prepare more complex structures for potential applications as molecular materials. Our previous works describe the preparation of some types of complexes with bidentate phosphine ligand, including bis(diphenylphosphino)methane, dppm, bis(diphenylphosphino) ethane, dppe and 1,1'-bis(diphenylphosphino)ferrocene, dppf $[54,55]$. For the purpose of designing new complexes potentially suitable for molecular wires based on platinum complexes, we have examined to the construction of novel dimers of cyclometalated platinum(II) complexes linked by the conjugated rigid diphosphine spacer, bis(diphenylphosphino)acetylene (dppac). The precursors used for this purpose are $\left[\mathrm{PtMe}(\mathrm{CN})\left(\mathrm{SMe}_{2}\right)\right](\mathrm{CN}=$ deprotonated 2phenylpyridine (ppy) or deprotonated benzo\{h\}quinoline (bhq)). In this paper, we describe the preparation, structural and spectroscopic characterization of binuclear cyclometalated platinum complexes connected by conjugated diphosphine, dppac. We also describe here the kinetic and mechanism of the reaction of $\mathrm{Pt}(\mathrm{II})-$ $\mathrm{Pt}(\mathrm{II})$ complexes with MeI to form new Pt(IV)-Pt(IV) complexes, the first binuclear cyclometalated Pt(IV) complexes containing dppac as bridging ligand.

\section{Experimental section}

The ${ }^{1} \mathrm{H},{ }^{13} \mathrm{C},{ }^{31} \mathrm{P}$ and ${ }^{195} \mathrm{Pt}$ NMR spectra were recorded on a Bruker Avance DRX $500 \mathrm{MHz}$ spectrometer in $\mathrm{CDCl}_{3}$ as solvent. The operating frequencies and references, respectively, are shown in parentheses as follows: ${ }^{1} \mathrm{H}$ (500 MHz, TMS), ${ }^{13} \mathrm{C}(125 \mathrm{MHz}, \mathrm{TMS})$, ${ }^{31} \mathrm{P}\left(202 \mathrm{MHz}, 85 \% \mathrm{H}_{3} \mathrm{PO}_{4}\right)$, and ${ }^{195} \mathrm{Pt}\left(107 \mathrm{MHz}\right.$, aqueous $\left.\mathrm{Na}_{2} \mathrm{PtCl}_{4}\right)$. The chemical shifts and coupling constants are in $\mathrm{ppm}$ and $\mathrm{Hz}$, respectively. Kinetic studies were carried out by using a PerkinElmer Lambda 25 spectrophotometer with temperature control using an EYELA NCB-3100 constant temperature bath. Benzo $\{\mathrm{h}\}$ quinoline, 2-phenylpyridine and bis(diphenylphosphino)acetylene were commercially available and the precursor compounds $\left[\mathrm{PtMe}(\mathrm{CN})\left(\mathrm{SMe}_{2}\right)\right](\mathrm{CN}=$ deprotonated 2-phenypyridine (ppy) or deprotonated benzo\{h\}quinoline (bhq)) were prepared according to reported procedures $[54,56,57]$. Scheme 1 shows the structural
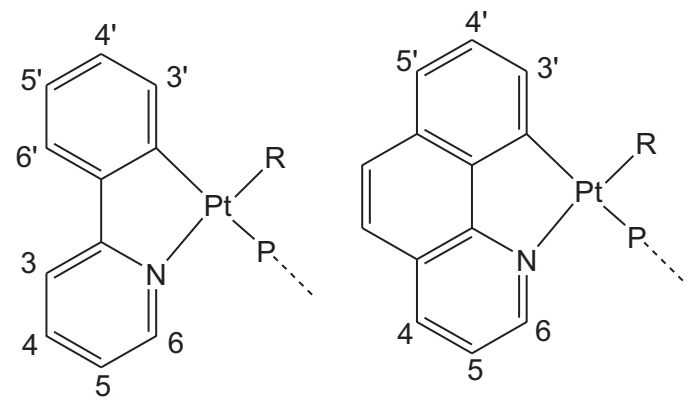

Scheme 1. Representation of $\mathrm{CN}$ ligands [ppy (left) and bhq (right)] with position labeling. formula of the $\mathrm{CN}$ ligands with the carbon atoms numbered to clarify the following chemical shift assignments.

\section{1. $\left[\mathrm{Pt}_{2} \mathrm{Me}_{2}(\text { ppy })_{2}(\mu-d p p a c)\right], \mathbf{1}$}

To a solution of [PtMe(ppy)(SMe $)](100 \mathrm{mg}, 0.23 \mathrm{mmol})$ in acetone $(15 \mathrm{~mL})$ was added 0.5 equiv bis(diphenylphosphino)acetylene (46 mg, $0.12 \mathrm{mmol}$ ) at room temperature. The mixture was stirred for $3 \mathrm{~h}$. The solvent was removed under reduced pressure, and the residue was washed with diethyl ether $(2 \times 3 \mathrm{~mL})$ and dried under vacuum. Yield $100 \mathrm{mg} ; 76 \%, \mathrm{mp} .230^{\circ} \mathrm{C}$ (decomp). Anal. Calcd. for $\mathrm{C}_{50} \mathrm{H}_{42} \mathrm{~N}_{2} \mathrm{P}_{2} \mathrm{Pt}_{2}$ : C, 53.5; H, 3.8; N, 2.5; Found: C, 53.8; H, 3.6; N, 2.3. NMR data: $\delta\left({ }^{1} \mathrm{H}\right) 0.70\left[\mathrm{~d},{ }^{3} J_{\mathrm{PH}}=8.9 \mathrm{~Hz},{ }^{2} J_{\mathrm{PtH}}=82.5 \mathrm{~Hz}, 6 \mathrm{H}, \mathrm{Me}\right.$ ligands], 6.40 [ddd, ${ }^{3} J_{\mathrm{HH}}^{3^{\prime} 4^{\prime}}=5.8 \mathrm{~Hz},{ }^{3} \mathrm{JH}_{\mathrm{H}}^{4^{\prime} 5^{\prime}}=8.6 \mathrm{~Hz},{ }^{5} J_{\mathrm{PH}}^{4^{\prime}}=1.3 \mathrm{~Hz}, 2 \mathrm{H}, \mathrm{H}^{4^{\prime}}$ of ppy], 7.10-7.37 (overlapping hydrogens), $7.42[\mathrm{t}$, ${ }^{3} J_{\mathrm{HH}}^{56} \approx{ }^{3} J_{\mathrm{HH}}^{54}=8.2 \mathrm{~Hz}, 2 \mathrm{H}, \mathrm{H}^{5}$ of ppy], $7.81\left[\mathrm{td},{ }^{3} J_{\mathrm{HH}}^{3^{\prime} 4^{\prime}} \approx{ }^{4} J_{\mathrm{PH}}^{3^{\prime}} \approx 6.0 \mathrm{~Hz}\right.$, ${ }^{4} J_{\mathrm{HH}}^{3^{\prime} 5^{\prime}}=1.4 \mathrm{~Hz},{ }^{3} J_{\mathrm{PtH}}^{3^{\prime}}=54.1 \mathrm{~Hz}, 2 \mathrm{H}, \mathrm{H}^{3^{\prime}}$ of ppy], $8.30\left[\mathrm{~d},{ }^{3} J_{\mathrm{HH}}^{56}=5.9 \mathrm{~Hz}\right.$, ${ }^{3} J_{\mathrm{PtH}}^{6}=14.8 \mathrm{~Hz}, 2 \mathrm{H}, \mathrm{H}^{6}$ of ppy $], \delta\left({ }^{31} \mathrm{P}\right) 12.6\left[\mathrm{~s},{ }^{1} J_{\mathrm{PtP}}=2049 \mathrm{~Hz}, 2 \mathrm{P}\right.$ of dppac]; $\delta\left({ }^{195} \mathrm{Pt}\right)-2594\left[\mathrm{~d},{ }^{1} J_{\mathrm{PtP}}=2047 \mathrm{~Hz}, 2 \mathrm{Pt}\right]$.

\section{2. $\left[\mathrm{Pt}_{2} \mathrm{Me}_{2}(\mathrm{bhq})_{2}(\mu-\mathrm{dppac})\right], \mathbf{2}$}

This was prepared by the method as described above for preparation of complex $\mathbf{1}$ using the starting materials [PtMe (bhq) $\left.\left(\mathrm{SMe}_{2}\right)\right]$ and dppac. Yield: $74 \%$, mp. $250{ }^{\circ} \mathrm{C}$ (decomp). Anal. Calcd. for $\mathrm{C}_{54} \mathrm{H}_{42} \mathrm{~N}_{2} \mathrm{P}_{2} \mathrm{Pt}_{2}$ : C, 55.4; $\mathrm{H}, 3.6$; N, 2.4; Found: C, 55.6; H, 3.5; $\mathrm{N}, 2.2$. NMR data: $\delta\left({ }^{1} \mathrm{H}\right) 0.88\left[\mathrm{~d},{ }^{2} \mathrm{JtH}=82.7 \mathrm{~Hz},{ }^{3} J_{\mathrm{PH}}=9.0 \mathrm{~Hz}, 6 \mathrm{H}, \mathrm{Me}\right.$ ligands], $6.60\left[\mathrm{dd},{ }^{3} \mathrm{~J}_{\mathrm{HH}}^{3^{\prime} 4^{\prime}}=6.1 \mathrm{~Hz},{ }^{3} \mathrm{~J}_{\mathrm{HH}}^{4^{\prime} 5^{\prime}}=8.0 \mathrm{~Hz}, 2 \mathrm{H}, \mathrm{H}^{4^{\prime}}\right.$ of bhq], $7.25-$ 7.76 (overlapping hydrogens), $8.10\left[\mathrm{td},{ }^{3} J_{\mathrm{HH}}^{3^{\prime} 4^{\prime}} \approx 4 J_{\mathrm{PH}}^{3^{\prime}} \approx 6.1 \mathrm{~Hz}\right.$, ${ }^{3} J_{\mathrm{HH}}^{3^{\prime} \mathrm{H}^{\prime}}=1.4 \mathrm{~Hz},{ }^{3} J_{\mathrm{PtH}}^{3_{\mathrm{P}}^{\prime}}=51.8 \mathrm{~Hz}, 2 \mathrm{H}, \mathrm{H}^{3^{\prime}}$ of bhq], $8.50\left[\mathrm{dt}^{3}{ }^{3} J_{\mathrm{HH}}^{65}=5.3 \mathrm{~Hz}\right.$, ${ }^{4} J_{\mathrm{HP}}^{6} \approx{ }^{4} J_{\mathrm{HH}}^{64} \approx 1.4 \mathrm{~Hz},{ }^{3} J_{\mathrm{PtH}}^{6}=14.7 \mathrm{~Hz}, 2 \mathrm{H}, \mathrm{H}^{6}$ of bhq]; $\delta\left({ }^{31} \mathrm{P}\right) 12.3[\mathrm{~s}$, ${ }^{1} J_{\mathrm{PtP}}=2102 \mathrm{~Hz}, 2 \mathrm{P}$ of dppac]; $\delta\left({ }^{195} \mathrm{Pt}\right)-2590$ [d, ${ }^{1} J_{\mathrm{PtP}}=2104 \mathrm{~Hz}, 2 \mathrm{Pt}$.

\section{3. $\left[\mathrm{Pt}_{2} \mathrm{I}_{2} \mathrm{Me}_{4}(\mathrm{ppy})_{2}(\mu-d p p a c)\right], 3$}

To a solution of $\left[\mathrm{Pt}_{2} \mathrm{Me}_{2} \text { (ppy) }\right)_{2}(\mu$-dppac)], 1, $(50 \mathrm{mg}$ in $25 \mathrm{~mL}$ $\left.\mathrm{CH}_{2} \mathrm{Cl}_{2}\right)$ was added an excess of $\mathrm{MeI}(550 \mu \mathrm{L})$ at room temperature and the mixture was stirred for $2 \mathrm{~h}$. The solvent was removed under reduced pressure, and the residue was washed with diethyl ether $(2 \times 3 \mathrm{~mL})$. The product was dried under vacuum. Yield $40 \mathrm{mg} ; 64 \%$, mp. $175{ }^{\circ} \mathrm{C}$ (decomp.). Anal. Calcd. for $\mathrm{C}_{52} \mathrm{H}_{48} \mathrm{I}_{2} \mathrm{~N}_{2} \mathrm{P}_{2} \mathrm{Pt}_{2}$ : C, 44.4; $\mathrm{H}$, 3.4; N, 2.0; Found: C, 44.2; H, 3.2; N, 1.7. NMR data: $\delta\left({ }^{1} \mathrm{H}\right) 1.16(\mathrm{~d}$, ${ }^{3} J_{\mathrm{PH}}=7.9 \mathrm{~Hz},{ }^{2} \mathrm{~J}_{\mathrm{PtH}}=62.1 \mathrm{~Hz}, 3 \mathrm{H}, 1 \mathrm{Me}$ group trans to $\left.\mathrm{P}\right), 1.17(\mathrm{~d}$, ${ }^{3} J_{\mathrm{PH}}=7.9 \mathrm{~Hz},{ }^{2} \mathrm{~J}_{\mathrm{PtH}}=62.0 \mathrm{~Hz}, 3 \mathrm{H}, 1 \mathrm{Me}$ groups trans to $\left.\mathrm{P}\right), 1.50(\mathrm{~d}$, ${ }^{3} J_{\mathrm{PH}}=8.7 \mathrm{~Hz},{ }^{2} \mathrm{JPtH}=70.1 \mathrm{~Hz}, 3 \mathrm{H}, 1 \mathrm{Me}$ group trans to $\left.\mathrm{N}\right), 1.52(\mathrm{~d}$, ${ }^{3} J_{\mathrm{PH}}=8.9 \mathrm{~Hz},{ }^{2} J_{\mathrm{PtH}}=70.3 \mathrm{~Hz}, 3 \mathrm{H}, 1 \mathrm{Me}$ group trans to $\mathrm{N}$ ), (aromatic protons): $6.8-7.9$ (overlapping multiplets), $9.42\left(\mathrm{~d},{ }^{3} \mathrm{~J}_{\mathrm{HH}}=5.2 \mathrm{~Hz}\right.$, ${ }^{3} J_{\mathrm{PtH}}=9 \mathrm{~Hz}, 1 \mathrm{H}, \mathrm{CH}$ group adjacent to coordinated $\mathrm{N}$ atom), 9.47 (d, ${ }^{3} \mathrm{JHH}_{\mathrm{HH}}=5.2 \mathrm{~Hz},{ }^{3} \mathrm{JtH}_{\mathrm{PtH}}=9 \mathrm{~Hz}, 1 \mathrm{H}, \mathrm{CH}$ group adjacent to coordinated $\mathrm{N}$ atom); $\delta\left({ }^{13} \mathrm{C}\right)-5.9\left(\mathrm{~d},{ }^{1} J_{\mathrm{PtC}}=628 \mathrm{~Hz},{ }^{2} J_{\mathrm{PC}}=23.6 \mathrm{~Hz}, 1 \mathrm{C}\right.$, Me trans to $\mathrm{N}),-5.7\left(\mathrm{~d},{ }^{1} \mathrm{JtC}_{\mathrm{PtC}}=628 \mathrm{~Hz},{ }^{2} \mathrm{JPC}_{\mathrm{PC}}=23.7 \mathrm{~Hz}, 1 \mathrm{C}\right.$, Me trans to $\left.\mathrm{N}\right), 6.9(\mathrm{~d}$, ${ }^{1} J_{\mathrm{PtC}}=509 \mathrm{~Hz},{ }^{2} J_{\mathrm{PC}}=116 \mathrm{~Hz}, 1 \mathrm{C}$, Me trans to $\left.\mathrm{P}\right), 7.1\left(\mathrm{~d},{ }^{1} \mathrm{~J}_{\mathrm{PtC}}=509 \mathrm{~Hz}\right.$, ${ }^{2} J_{\mathrm{PC}}=116 \mathrm{~Hz}, 1 \mathrm{C}$, Me trans to P), 101.7 (d, with ${ }^{1} J_{\mathrm{PC}}=66.2 \mathrm{~Hz}, 1 \mathrm{C},-$ $\mathrm{C} \equiv \mathrm{C}), 101.9$ (d, with $\left.{ }^{1} J_{\mathrm{PC}}=66.2 \mathrm{~Hz}, 1 \mathrm{C},-\mathrm{C} \equiv \mathrm{C}\right), 147.0,147.1$ (each a doublet, with ${ }^{2} J_{\mathrm{PC}}=13.6 \mathrm{~Hz},{ }^{1} J_{\mathrm{PtC}}=888 \mathrm{~Hz}, 2 \mathrm{C}, \mathrm{C}$ atoms of the ppy ligands connected to $\mathrm{Pt}$ atoms), other aromatic Cs were not assigned; $\delta\left({ }^{31} \mathrm{P}\right)-23.9\left(\mathrm{~s},{ }^{1} J_{\mathrm{PtP}}=976 \mathrm{~Hz}, 1 \mathrm{P}\right),-23.7\left(\mathrm{~s},{ }^{1} J_{\mathrm{PtP}}=977 \mathrm{~Hz}\right.$, $1 \mathrm{P}) ; \delta\left({ }^{195} \mathrm{Pt}\right)-1797$ and -1806 (2 overlapping $\mathrm{d}$, each with $\left.{ }^{1} J_{\mathrm{PtP}}=975 \mathrm{~Hz}, 2 \mathrm{Pt}\right)$.

\section{4. $\left[\mathrm{Pt}_{2} \mathrm{I}_{2} \mathrm{Me}_{4}(\mathrm{bhq})_{2}(\mu-\mathrm{dppac})\right], 4$}

This was prepared by the method as described above for preparation of complex 3 using the starting material $\left[\mathrm{Pt}_{2} \mathrm{Me}_{2}(\mathrm{bhq})_{2}(\mu-\right.$ dppac)], 2. Yield: $64 \%$, mp. $190{ }^{\circ} \mathrm{C}$ (decomp.). Anal. Calcd. for 
Table 1

Crystal data, data collection, and structure refinement details for complexes $\mathbf{2}$ and $\mathbf{3}$.

\begin{tabular}{lll}
\hline & Complex 2 & Complex 3 \\
\hline Formula & $\mathrm{C}_{54} \mathrm{H}_{42} \mathrm{~N}_{2} \mathrm{P}_{2} \mathrm{Pt}_{2}$ & $\mathrm{C}_{52} \mathrm{H}_{48} \mathrm{I}_{2} \mathrm{~N}_{2} \mathrm{P}_{2} \mathrm{Pt}_{2}$ \\
Formula weight & 1171.02 & 1406.84 \\
Temperature/K & $291(2)$ & $100(2)$ \\
Crystal system & Triclinic & Monoclinic \\
Space group & $P-1$ & $P 2(1) / c$ \\
$a / \AA$ & $9.6765(10)$ & $14.7189(4)$ \\
$b / \AA$ & $9.8839(10)$ & $16.7379(5)$ \\
$c / \AA$ & $23.624(3)$ & $19.4066(6)$ \\
vol $/ \AA^{3}$ & $2235.8(4)$ & $4725.2(2)$ \\
$Z$ & 2 & 4 \\
$D($ calc $) / \mathrm{Mg} \mathrm{m}^{-3}$ & 1.739 & 1.978 \\
$\mu / \mathrm{mm}{ }^{-1}$ & 6.361 & 7.326 \\
$T_{\text {min }} / T_{\text {max }}$ & $0.884 / 1.000$ & $0.234 / 0.322$ \\
$F(000)$ & 1132 & 2664 \\
No. of reflns & 15,489 & 43,031 \\
No. of independent reflns & $8049[R($ int $)=0.0542]$ & $9667[R($ int $)=0.0603]$ \\
No. of observed reflns & 5143 & 7771 \\
{$[I>2 \sigma(I)]$} & & \\
GooF $\left(F^{2}\right)$ & 0.75 & 1.122 \\
$R 1, w R 2[I>2 \sigma(I)]$ & $0.0285,0.0475$ & $0.0373,0.0592$ \\
$R 1, w R 2($ all data $)$ & $0.0589,0.0509$ & $0.0556,0.0631$ \\
\hline
\end{tabular}

$\mathrm{C}_{56} \mathrm{H}_{48} \mathrm{I}_{2} \mathrm{~N}_{2} \mathrm{P}_{2} \mathrm{Pt}_{2}$ : C, 46.2; H, 3.3; N, 1.9; Found: C, 46.5; H, 3.2; N, 1.7. NMR data: $\delta\left({ }^{1} \mathrm{H}\right) 1.14\left(\mathrm{~d},{ }^{2} J_{\mathrm{PtH}}=62.2 \mathrm{~Hz},{ }^{3} J_{\mathrm{PH}}=7.9 \mathrm{~Hz}, 3 \mathrm{H}, 1 \mathrm{Me}\right.$ group trans to P), 1.16 (d, ${ }^{3} J_{\mathrm{PH}}=7.9 \mathrm{~Hz},{ }^{2} J_{\mathrm{PtH}}=62.6 \mathrm{~Hz}, 3 \mathrm{H}, 1 \mathrm{Me}$ groups trans to P), $1.65\left(\mathrm{~d},{ }^{3} J_{\mathrm{PH}}=8.7 \mathrm{~Hz},{ }^{2} \mathrm{~J}_{\mathrm{PtH}}=70.1 \mathrm{~Hz}, 3 \mathrm{H}, 1 \mathrm{Me}\right.$ group trans to N), 1.67 (d, ${ }^{3} J_{\mathrm{PH}}=8.7 \mathrm{~Hz},{ }^{2} \mathrm{JPtH}=70.0 \mathrm{~Hz}, 3 \mathrm{H}, 1 \mathrm{Me}$ group trans to $\mathrm{N}$ ), (aromatic protons): $6.9-8.1$ (overlapping multiplets), $9.50\left(\mathrm{~d},{ }^{3} \mathrm{~J}_{\mathrm{HH}}=5.1 \mathrm{~Hz},{ }^{3} \mathrm{JPtH}_{\mathrm{PH}}=11 \mathrm{~Hz}, 1 \mathrm{H}, \mathrm{CH}\right.$ group adjacent to coordinated $\mathrm{N}$ atom), $9.60\left(\mathrm{~d},{ }^{3} J_{\mathrm{HH}}=5.3 \mathrm{~Hz},{ }^{3} J_{\mathrm{PtH}}=11 \mathrm{~Hz}, 1 \mathrm{H}, \mathrm{CH}\right.$ group adjacent to coordinated $\mathrm{N}$ atom); $\delta\left({ }^{13} \mathrm{C}\right)-6.7\left(\mathrm{~d},{ }^{1} \mathrm{~J}_{\mathrm{PtC}}=\right.$ $622 \mathrm{~Hz},{ }^{2} J_{\mathrm{PC}} \approx 3 \mathrm{~Hz}, 1 \mathrm{C}$, Me trans to $\left.\mathrm{N}\right),-6.5\left(\mathrm{~d},{ }^{1} J_{\mathrm{PtC}}=624 \mathrm{~Hz}\right.$, ${ }^{2} J_{\mathrm{PC}}=3.7 \mathrm{~Hz}, 1 \mathrm{C}$, Me trans to N), $6.2\left(\mathrm{~d},{ }^{1} \mathrm{JPtC}_{\mathrm{PtC}}=505 \mathrm{~Hz},{ }^{2} \mathrm{JPC}_{\mathrm{PC}}=115 \mathrm{~Hz}\right.$, 1C, Me trans to P), 6.5 (d, ${ }^{1} \mathrm{JtC}=504 \mathrm{~Hz},{ }^{2} J_{\mathrm{PC}}=115 \mathrm{~Hz}, 1 \mathrm{C}$, Me trans to $\mathrm{P}$ ), 101.3 (d, with ${ }^{1} J_{\mathrm{PC}}=66 \mathrm{~Hz}, 1 \mathrm{C},-\mathrm{C} \equiv \mathrm{C}$ ), 101.8 (d, with $\left.{ }^{1} J_{\mathrm{PC}}=66 \mathrm{~Hz}, 1 \mathrm{C},-\mathrm{C} \equiv \mathrm{C}\right)$, other aromatic C's were not assigned; $\delta\left({ }^{31} \mathrm{P}\right)-23.9\left(\mathrm{~s},{ }^{1} J_{\mathrm{PtP}}=975 \mathrm{~Hz}, 1 \mathrm{P}\right),-23.6\left(\mathrm{~s},{ }^{1} J_{\mathrm{PtP}}=976 \mathrm{~Hz}, 1 \mathrm{P}\right)$; $\delta\left({ }^{195} \mathrm{Pt}\right)-1832$ and -1823 (2 overlapping $\mathrm{d}$, each with $\left.{ }^{1} J_{\mathrm{PtP}}=978 \mathrm{~Hz}, 2 \mathrm{Pt}\right)$.

\subsection{Reaction of $\left[\mathrm{Pt}_{2} \mathrm{Me}_{2}(\text { ppy })_{2}(\mu\right.$-dppac)], 1, with MeI}

This reaction was monitored by ${ }^{31} \mathrm{P}$ NMR spectroscopy at room temperature in an NMR tube. To a solution of $\left[\mathrm{Pt}_{2} \mathrm{Me}_{2}(\mathrm{ppy})_{2}(\mu-\right.$ dppac)], 1, (10 mg) in $\mathrm{CDCl}_{3}(0.7 \mathrm{~mL})$, an excess of MeI $(3 \mu \mathrm{L})$ was added. The NMR spectra were recorded several times at during about 2 h until the mixture was gradually converted to complex 3 in solution.

\subsection{Kinetic study}

In a typical experiment, a solution of complex 1 in $\mathrm{CHCl}_{3}$ $\left(3 \mathrm{~mL}, 1.06 \times 10^{-4} \mathrm{M}\right.$ ) in a cuvette was thermostated at $25^{\circ} \mathrm{C}$ and a known excess of MeI was added using a micro syringe. After rapid stirring, the absorbance at $\lambda=352 \mathrm{~nm}$ was monitored with time.

\subsection{Crystallography}

Single crystal of $\left.\left[\mathrm{Pt}_{2} \mathrm{Me}_{2} \text { (bhq) }\right)_{2}(\mu-\mathrm{dppac})\right], 2$, was grown from a concentrated $\mathrm{CH}_{2} \mathrm{Cl}_{2}$ solution by slow diffusion of $n$-pentane. Single crystal X-ray data for complex 2 were collected at 296(1) K on STOE IPDS 2T diffractometer (Mo $K \alpha=0.71073 \AA$ ). The cell parameters were retrieved using X-AREA [58] software and refined using X-AREA on all observed reflections. Data reduction and correction for Lp (Lorentz-polarization) and decay were performed using X-AREA software. Absorption corrections were applied using MULABS [59,60]. All structures were solved by direct methods and refined by full-matrix least squares on $F^{2}$ for all data using SHELXTL software [61]. All calculations were performed by PLATON. All non-hydrogen atoms were refined anisotropically. Hydrogen atoms were positioned geometrically and refined with a riding model approximation with their parameters constrained to the parent atom with $U_{\text {iso }}(\mathrm{H})=1.2$ or 1.5 $U_{\text {eq }}(\mathrm{C})$. Single crystal of $\left[\mathrm{Pt}_{2} \mathrm{I}_{2} \mathrm{Me}_{4}(\mathrm{ppy})_{2}(\mu\right.$-dppac)], 3, was grown from a concentrated $\mathrm{CH}_{2} \mathrm{Cl}_{2}$ solution by slow diffusion of $n$ pentane. The single crystal X-ray diffraction study of $\mathbf{3}$ was carried out on a Bruker Platform D8 CCD diffractometer equipped with Mo $\mathrm{K}_{\alpha}$ radiation $(\lambda=0.71073)$. A $0.28 \times 0.24 \times 0.20 \mathrm{~mm}$
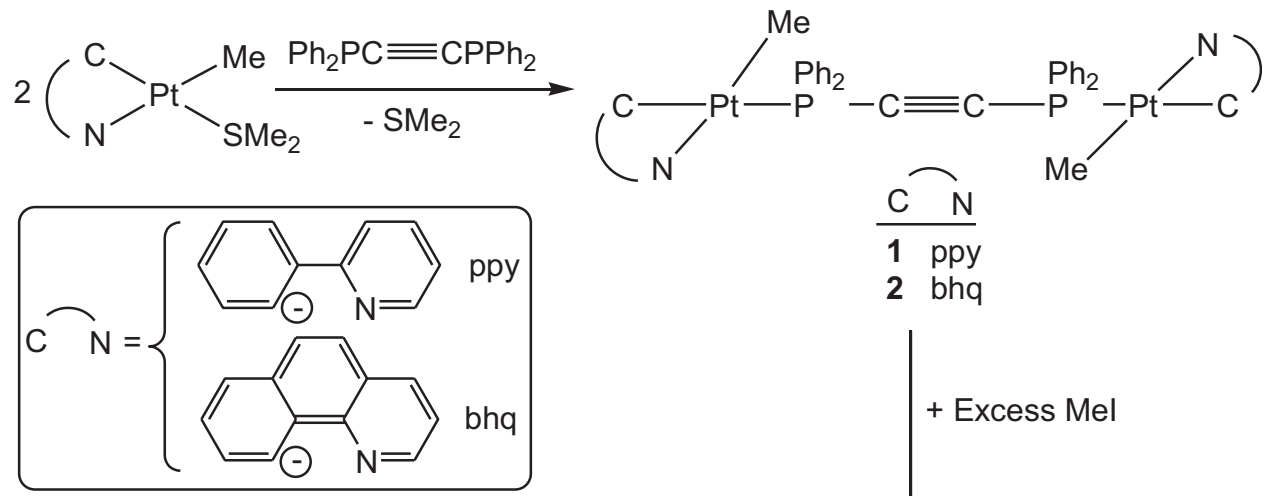

2 bha
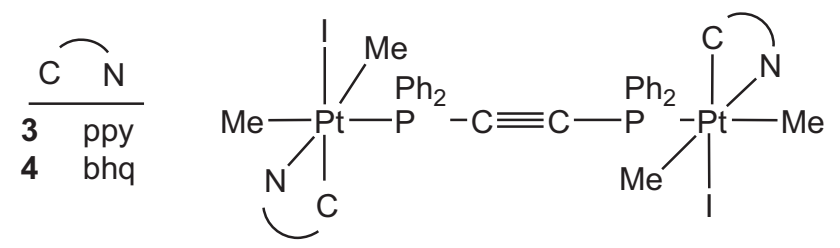

Scheme 2. Reactions studied in this work. 


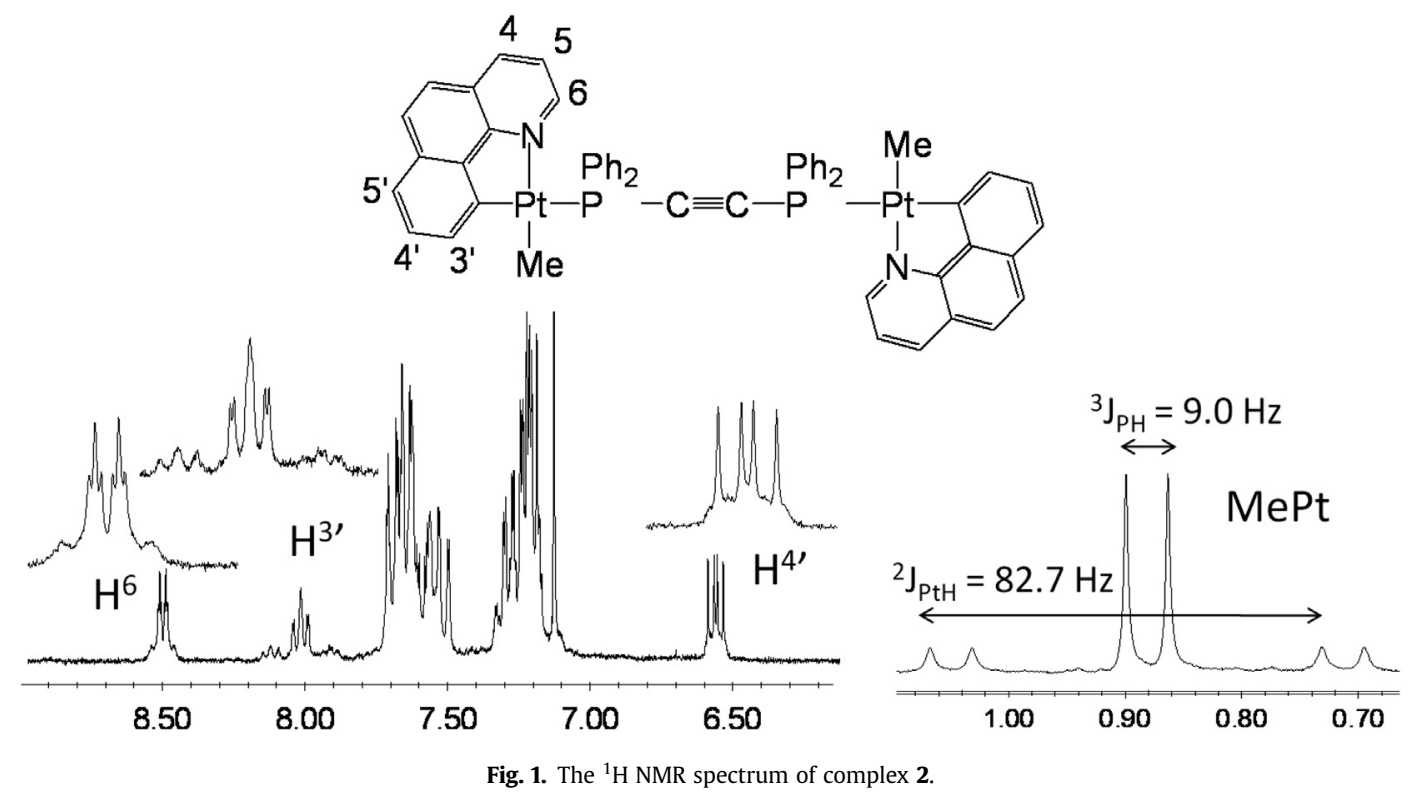

crystal was mounted on a Cryo-loop with Paratone-N. The Bruker program packages, APEX-II and SAINT were used for data collection, integration and corrections. Solution and refinement proceeded as described for complex 2. At both $\mathrm{Pt}(\mathrm{IV})$ sites of complex 3, there was iodide/methyl group disorder; the minority component is designated with a prime. The major configuration at Pt1 is $71 \%$ occupied, and at Pt2, 88\% occupied. The occupancies were refined with a unit occupancy constraint. Crystal data, data collection, and structure refinement details are listed in Table 1.

\section{Results and discussion}

\subsection{Synthesis and characterization of the Pt(II)-Pt(II) complexes}

The synthetic procedures are summarized in Scheme 2.

The starting complexes [PtMe $\left.(\mathrm{CN})\left(\mathrm{SMe}_{2}\right)\right]$, in which $\mathrm{CN}=$ ppy or bhq, reacted with bis(diphenylphosphino)acetylene (dppac) in a 1:0.5 molar ratio to give the organodiplatinum(II) complexes $\left[\mathrm{PtMe}_{2}(\mathrm{CN})_{2}(\mu\right.$-dppac)], 1-2. They were isolated as stable solids

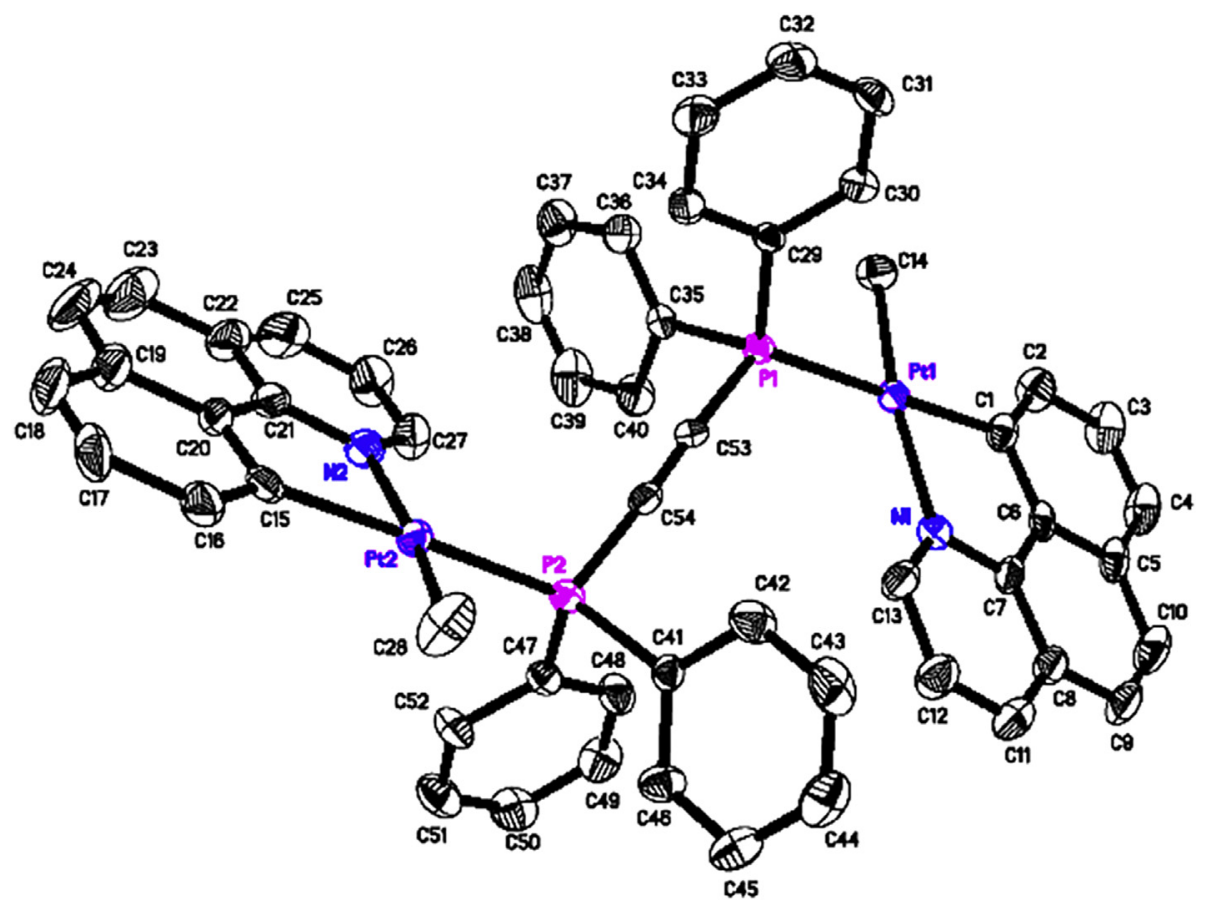

Fig. 2. (a) The molecular structure of complex $\left[\mathrm{Pt}_{2} \mathrm{Me}_{2}(\mathrm{bhq})_{2}(\mu\right.$-dppac)], 2, showing $40 \%$ probability ellipsoids. The $\mathrm{H}$ atoms omitted for clarity. Selected bond distances $(\AA)$ and angles ( ${ }^{\circ}$ : $\mathrm{Pt}(1)-\mathrm{C}(1)$ 2.059(7); $\mathrm{Pt}(1)-\mathrm{C}(14)$ 2.069(6); $\mathrm{Pt}(1)-\mathrm{N}(1)$ 2.130(5); $\mathrm{Pt}(1)-\mathrm{P}(1)$ 2.2672(17); $\mathrm{Pt}(2)-\mathrm{C}(15)$ 2.053(7); $\mathrm{Pt}(2)-\mathrm{C}(28) 2.066(6) ; \mathrm{Pt}(2)-\mathrm{N}(2)$ 2.144(5); $\mathrm{Pt}(2)-\mathrm{P}(2)$ 2.2750(18); $\mathrm{P}(2)-\mathrm{C}(54)$ 1.783(7); $\mathrm{P}(2)-\mathrm{C}(47)$ 1.824(7); $\mathrm{P}(2)-\mathrm{C}(41)$ 1.840(6); $\mathrm{P}(1)-\mathrm{C}(53)$ 1.779(7); $\mathrm{P}(1)-\mathrm{C}(29)$ 1.836(6); $\mathrm{P}(1)-\mathrm{C}(35)$ 1.839(6); $\mathrm{C}(1)-\mathrm{Pt}(1)-\mathrm{C}(14)$ 89.6(3); $\mathrm{C}(1)-\mathrm{Pt}(1)-$ $\mathrm{N}(1)$ 80.3(2); C(14)-Pt(1)-N(1) 169.7(2); C(1)-Pt(1)-P(1) 173.85(19); C(14)-Pt(1)-P(1) 85.81(19); N(1)-Pt(1)-P(1) 104.44(15); C(15)-Pt(2)-C(28) 91.2(3); C(15)-Pt(2)-N(2) 80.6(3); C(28)-Pt(2)-N(2) 171.8(3); C(15)-Pt(2)-P(2) 176.7(2); C(28)-Pt(2)-P(2) 91.2(2). 
which were characterized by their ${ }^{1} \mathrm{H},{ }^{31} \mathrm{P}$ and ${ }^{195} \mathrm{Pt}$ NMR spectra and elementary analysis and the structure of complex $\mathbf{2}$ was further determined by X-ray crystallography. Typically, in the ${ }^{1} \mathrm{H}$ NMR spectrum of $\left[\mathrm{Pt}_{2} \mathrm{Me}_{2} \text { (bhq) }\right)_{2}\left(\mu\right.$-dppac)], 2 , in $\mathrm{CDCl}_{3}$ at room temperature (see Fig. 1), the methylplatinum resonance appeared at $\delta=0.88$ as a doublet due to coupling to phosphorus (with ${ }^{3} J_{\mathrm{PH}}=9.0 \mathrm{~Hz}$ ) which is further coupled to ${ }^{195} \mathrm{Pt}$ ( with ${ }^{2} J_{\mathrm{PtH}}=82.7 \mathrm{~Hz}$ ) confirming that the methyl ligands are located trans to aromatic $\mathrm{N}$ atoms, which is characteristic values for Pt-Me trans to N [62-64]. The hydrogen related to the $\mathrm{CH}$ group adjacent to ligating $\mathrm{N}$ atom of the $\mathrm{CN}$ ligand appeared as a doublet of triplet at $\delta=8.50$ with ${ }^{3} J_{\mathrm{HH}}^{65}=5.3 \mathrm{~Hz},{ }^{4} J_{\mathrm{HP}}^{6} \approx{ }^{4} J_{\mathrm{HH}}^{64} \approx 1.4 \mathrm{~Hz}$ and ${ }^{3} J_{\mathrm{HPt}}^{6}=14.7 \mathrm{~Hz}$. The hydrogen related to the $\mathrm{CH}$ group adjacent to ligating $\mathrm{C}$ atom of the $\mathrm{CN}$ ligand appeared as a triplet of doublet at $\delta=8.10$ with $^{3} J_{\mathrm{H}}^{3^{\prime} 4^{\prime}} \approx{ }^{4} J_{\mathrm{HP}}^{3^{\prime}} \approx 6.1 \mathrm{~Hz}$,
${ }^{4} J_{\mathrm{HH}}^{3^{\prime} 5^{\prime}}=1.4 \mathrm{~Hz}$ and ${ }^{3} J_{\mathrm{HPt}}^{3^{\prime}}=51.8 \mathrm{~Hz}$. In the room temperature ${ }^{31} \mathrm{P} \mathrm{NMR}$ spectrum of the binuclear complex 2 , the observation of a sharp singlet signal for each of the analogs at a chemical shift of $12.3 \mathrm{ppm}$, which is accompanied by Pt satellites, ${ }^{1} J_{\mathrm{PtP}}=2102 \mathrm{~Hz}$, confirm that the two PtMe(bhq) moieties, joined together by the dppac spacer ligand, are equivalent. Consistent with this, in the ${ }^{195} \mathrm{Pt}$ NMR spectrum of 2 , a doublet at $\delta-2590$ with ${ }^{1} J_{\mathrm{PtP}}=2104 \mathrm{~Hz}$ was observed. This ${ }^{1} J_{\mathrm{PtP}}$ value is consistent with $\mathrm{P}$ trans to a ligand with high trans influence like carbon; trans to $\mathrm{N}$ would give a larger coupling constant [64-66]. These data suggest that dppac is acting as a spacer ligand between the two PtMe(bhq) moieties and each $\mathrm{P}$ atom is coordinated to a Pt atom in a trans disposition to coordinating $\mathrm{C}$ atom of the phenyl ring of bhq ligand. Each Me ligand is thus located trans to the coordinated $\mathrm{N}$ atom of bhq ligand.
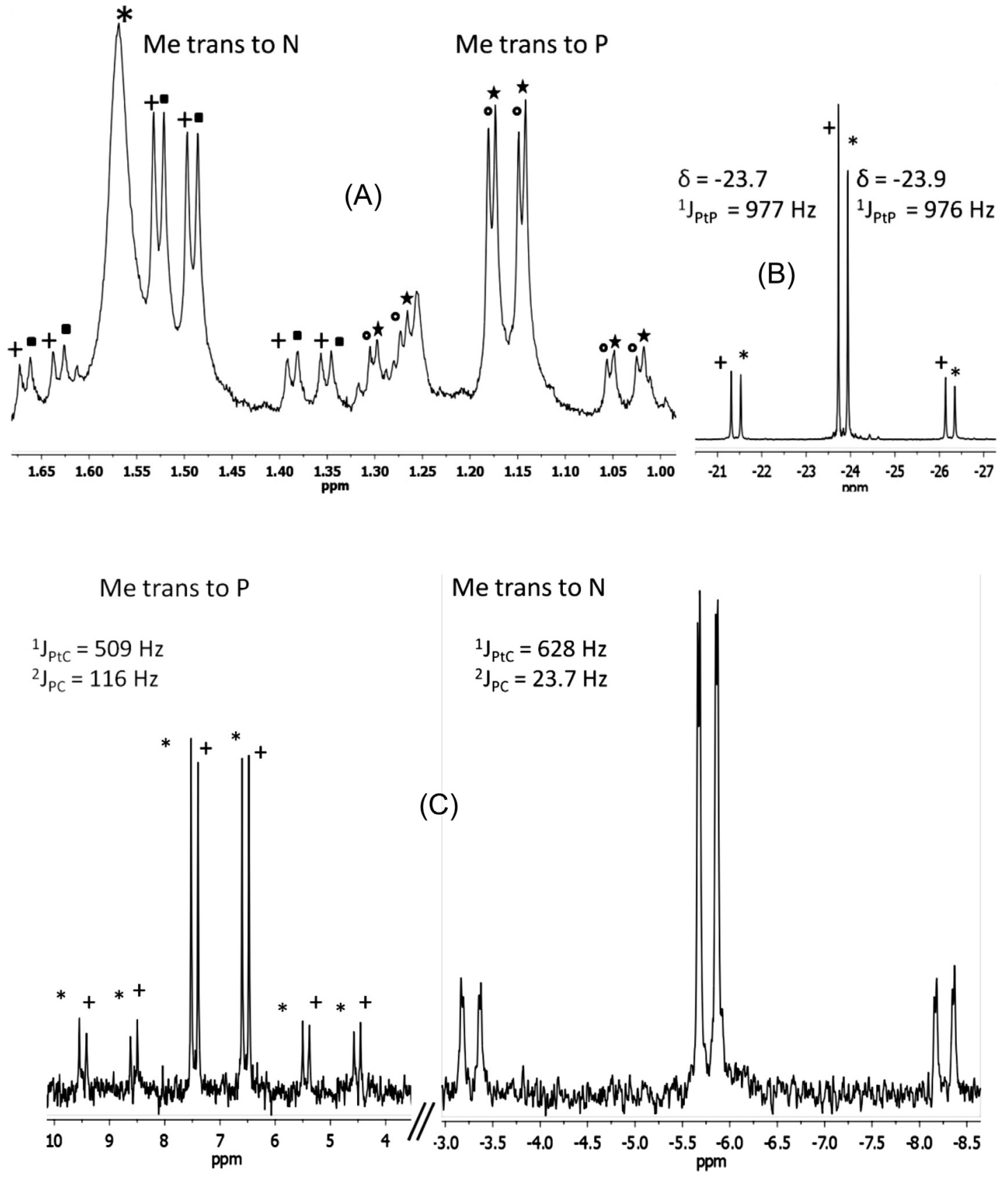

Me trans to $\mathrm{N}$
$\begin{aligned} & { }^{1} \mathrm{~J}_{\mathrm{PtC}}=628 \mathrm{~Hz} \\ & { }^{2} \mathrm{JPC}_{\mathrm{PC}}=23.7 \mathrm{~Hz}\end{aligned}$

(C)

Fig. 3. The NMR spectra of complex 3. (A): ${ }^{1} \mathrm{H}$ in the Me region; (B): ${ }^{31} \mathrm{P}$ NMR and $(\mathrm{C}){ }^{13} \mathrm{C}$ NMR in the Me region. The peak labeled ${ }^{*}$ in ${ }^{1} \mathrm{H}$ NMR is due to water of $\mathrm{CDCl} 3$ solvent. 


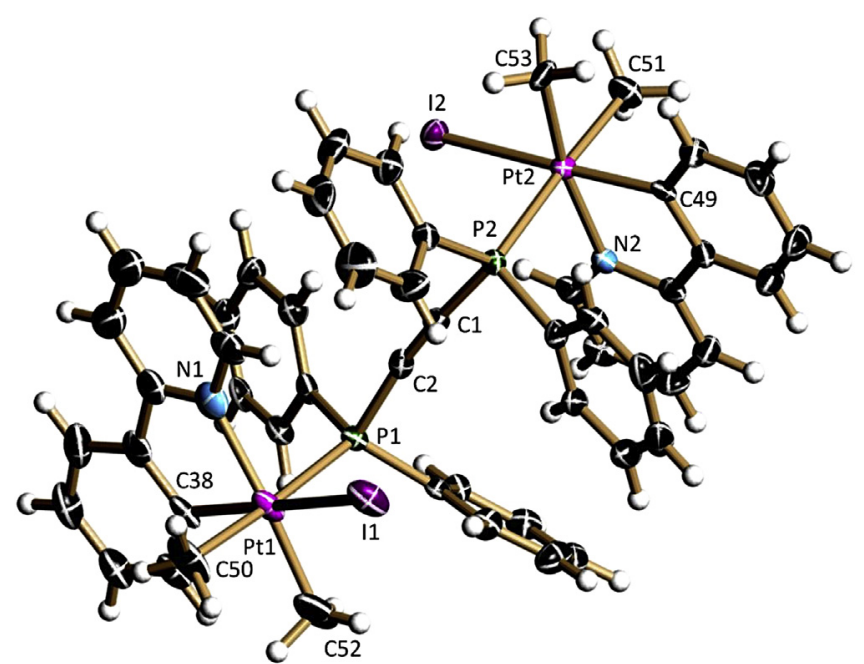

Fig. 4. (a) The molecular structures of complex $\left[\mathrm{Pt}_{2} \mathrm{I}_{2} \mathrm{Me}_{4}(\mathrm{ppy})_{2}(\mu-\mathrm{dppac})\right]$, 3. Selected bond distances $(\AA)$ and angles $\left({ }^{\circ}\right)$ : Pt1-C38 2.074(6); Pt1-C50 2.102(6); Pt1-C52 2.089(14); Pt1-N1 2.112(6); Pt1-I1 2.7343(7); Pt1-P1 2.3886(14); Pt2-C49 2.037(5); Pt2-C51 2.102(5); Pt2-C53 2.051(9); Pt2-N2 2.133(5); Pt2-I2 2.7378(5); Pt2-P2 2.4146(14); C38-Pt1-C52 92.4(4); C50-Pt1-C52 92.0(4); C38-Pt1-N1 80.3(2); C50Pt1-N1 89.2(3); C52-Pt1-N1 172.5(4); C38-Pt1-P1 92.41(16); C50-Pt1-P1 176.7(2); N1-Pt1-P1 87.57(13); C38-Pt1-I1 175.12(17); N1-Pt1-I1 97.47(15); P1-Pt1-I1 91.82(4); C49-Pt2-C51 87.5(2); C49-Pt2-N2 79.8(2); C53-Pt2-N2 170.3(3); C51Pt2-N2 88.7(2); C49-Pt2-P2 92.63(15); C51-Pt2-P2 175.36(18); N2-Pt2-P2 86.80(12); C49-Pt2-I2 175.90(15); C53-Pt2-I2 90.6(2); N2-Pt2-I2 98.08(13); P2Pt2-I2 90.72(4).

When more than 0.5 equiv of dppac (e.g., [PtMe $(\mathrm{CN}$ ) $\left.\left(\mathrm{SMe}_{2}\right)\right]$ :dppac $\left.=1: 1\right)$ is used in the related reaction, on the basis of the ${ }^{1} \mathrm{H}$ and ${ }^{31} \mathrm{P}$ NMR spectra, only the corresponding dimer was formed as a mixture with free dppac.

The structure of complex $\left[\mathrm{Pt}_{2} \mathrm{Me}_{2} \text { (bhq) }\right)_{2}(\mu$-dppac)], 2, was further determined by X-ray crystallography and is shown in Fig. 2; the selected bond lengths and bond angles are also shown. The geometry around the $\mathrm{Pt}(\mathrm{II})$ atoms in complex $\mathbf{2}$ is slightly-distorted square-planar with mean deviation of $0.026(3) \AA$ for Pt1 [C1/N1/ $\mathrm{C} 14 / \mathrm{P} 1$ plane] and -0.021 (3) $\AA$ for Pt2 [C15/N2/C28/P2 plane]. The complex 2 is formed by two identical moieties "PtMe(bhq)" connected by $\mathrm{P}$ atoms of dppac ligand. The fragment $\mathrm{P}-\mathrm{C}-\mathrm{C}-\mathrm{P}$ is almost linear $\left[\mathrm{P} 1-\mathrm{C} 53-\mathrm{C} 54174.4(5)^{\circ}\right]$ and the Pt1-P1, P1-C53 and Pt1-N1 distances are 2.2672(17), 1.779(7) and 2.130(5) A, respectively. The terminal Me ligands are in a transoidal disposition; the unique $\mathrm{C} \equiv \mathrm{C}$ distance is 1.199(7) $\AA$. The square-planar environment for both platinum centers is completed by the aromatic $\mathrm{N}$ atom and the ortho $\mathrm{C}$ of the bhq ligand forming cycloplatinated complex. Mono $\mu$-dppac complexes which a dppac molecule acts as a unique bridging ligand between two metal fragments are not very common [31].

\subsection{Synthesis and characterization of Pt(IV)-Pt(IV) complexes}

The methylplatinum(II) complexes, $\mathbf{1}$ and $\mathbf{2}$, were reacted cleanly with an excess of $\mathrm{MeI}$ in $\mathrm{CH}_{2} \mathrm{Cl}_{2}$ at room temperature to give air-stable solid products having the general formula $\left[\mathrm{Pt}_{2} \mathrm{I}_{2}\right.$ $\mathrm{Me}_{4}(\mathrm{CN})_{2}(\mu$-dppac)] (CN = ppy, 3; bhq, 4). The synthesized Pt(IV) complexes were fully characterized using ${ }^{1} \mathrm{H},{ }^{13} \mathrm{C},{ }^{31} \mathrm{P}$ and ${ }^{195} \mathrm{Pt}$ NMR spectroscopy and elemental analysis. Complex $\mathbf{3}$ was further identified by single crystal X-ray structure determination. Full data are collected in the Experimental section. On the base of ${ }^{1} \mathrm{H}$ and ${ }^{13} \mathrm{C}$ NMR spectra of complex [ $\mathrm{Pt}_{2} \mathrm{I}_{2} \mathrm{Me}_{4}$ (ppy $)_{2}$ ( $\mu$-dppac)], 3, (see Fig. 3), two different Me groups being trans to $\mathrm{P}$ and two different Me groups locating trans to $\mathrm{N}$ ligating atoms were assigned. Thus, in the ${ }^{1}$ H NMR spectrum of complex 3 (see Fig. 3A), the Me groups trans to P were observed at $\delta 1.16$ and 1.17 as doublets with, ${ }^{2} J_{\mathrm{PtH}}=62.1$ and $62.0 \mathrm{~Hz}$, respectively, while Me groups locating trans to $\mathrm{N}$ ligating atoms were appeared at $\delta 1.50$ and 1.52 , with a considerably higher ${ }^{2} J_{\mathrm{PtH}}$ values of 70.1 and 70.3 , respectively, due to lower trans influence of $\mathrm{N}$ atom as compared with that of $\mathrm{P}$ atom [66,67]. The hydrogen related to the $\mathrm{CH}$ groups adjacent to ligating $\mathrm{N}$ atom of the ppy ligands appeared as a doublet at $\delta=9.40$ and 9.50 each with ${ }^{3} J_{\mathrm{HH}}=5.2 \mathrm{~Hz}$ and ${ }^{3} J_{\mathrm{PtH}}=9.0 \mathrm{~Hz}$. Consistently, in the ${ }^{13} \mathrm{C} \mathrm{NMR}$ spectrum of 3, in the Me region (see Fig. 3C), two doublets were appeared at $\delta 6.9$ and 7.1 with a ${ }^{2} J_{\mathrm{PC}}$ value close to $116 \mathrm{~Hz}$ for the Me groups trans to P; each doublet further coupled to platinum to give a ${ }^{1} \mathrm{PtC}$ value close to $509 \mathrm{~Hz}$. Two other doublets were appeared further high field at $\delta-5.9$ and -5.7 each with a ${ }^{2} J_{\mathrm{PC}}$ value of close to $23.6 \mathrm{~Hz}$, indicating that they are located cis to $\mathrm{P}$ atom and thus must be trans to $\mathrm{N}$ atom; the ${ }^{1} J_{\mathrm{PtC}}$ value of $628 \mathrm{~Hz}$ for each of the signals is also significantly higher than the value of $508 \mathrm{~Hz}$ found

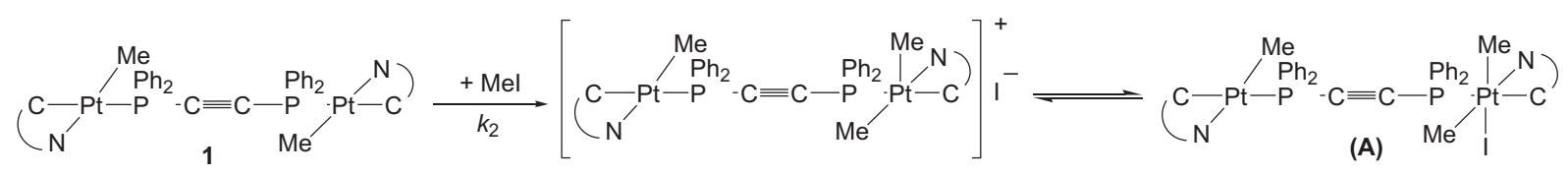

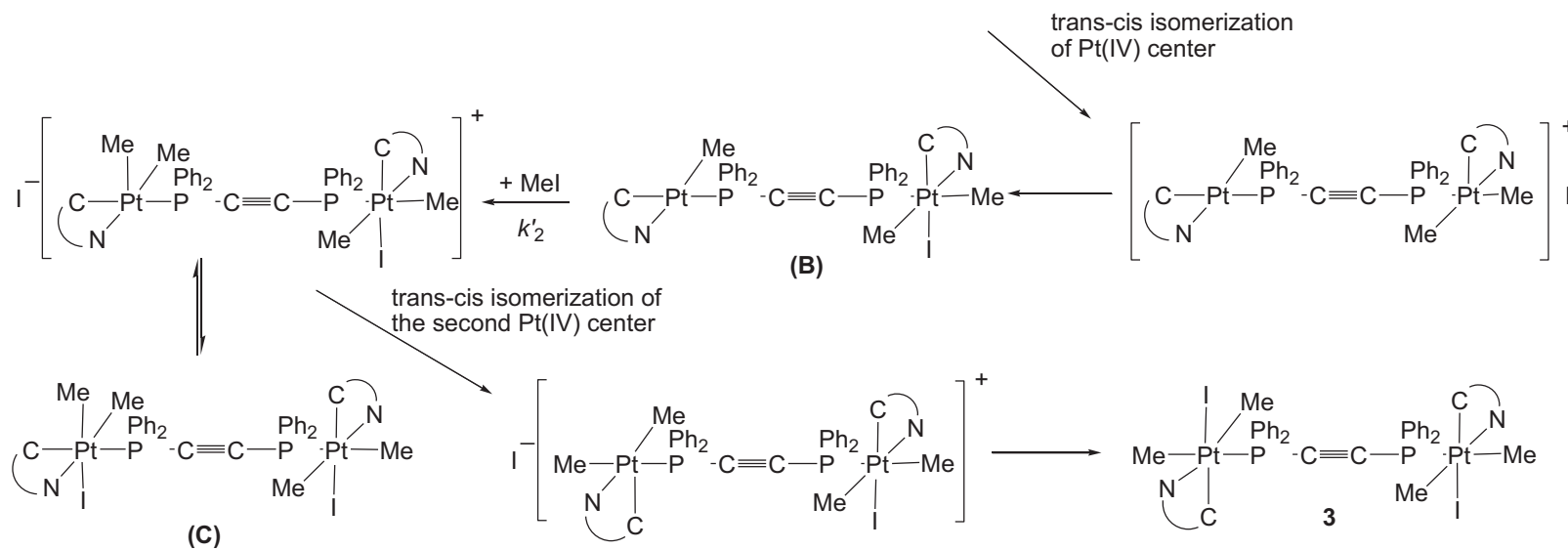

Scheme 3. Suggested mechanism for reaction of complexes $\mathbf{1}$ and $\mathbf{2}$ with MeI. 
for Me groups trans to $\mathrm{P}$ atoms. In the ${ }^{31} \mathrm{P}$ NMR spectrum of $\left[\mathrm{Pt}_{2} \mathrm{I}_{2} \mathrm{Me}_{4}(\mathrm{ppy})_{2}\right.$ ( $\mu$-dppac)], 3, (see Fig. 3B) two different $\mathrm{P}$ signals at $\delta-23.7$ and -23.9 with ${ }^{1} J_{\mathrm{PtP}}=977$ and $976 \mathrm{~Hz}$, respectively, which as expected is much lower than the corresponding value of $2049 \mathrm{~Hz}$ found for the starting Pt(II) complex 1, were observed and these are consistent with the observation of two signals in the ${ }^{195} \mathrm{Pt}$ NMR spectrum of complex 3 at $\delta-1797$ and -1806 (two almost overlapping doublets each with ${ }^{1} J_{\mathrm{PtP}}=975 \mathrm{~Hz}$ ). These data would well establish the relative disposition of the different ligands on each Pt center as shown in Scheme 1 (with chirality at each Pt center), but it is not possible to use the present data to actually propose any "frozen" conformer(s) for complexes $\mathbf{3}$ and $\mathbf{4}$ resulting from rotation around one or two of the Pt-P bonds. As twice the "expected" number of signals was observed in the NMR spectra of complex $\mathbf{3}$, the formation of a statistical 1:1 mixture of two stereoisomers may be a reasonable explanation.

Complex 3 was also characterized by single-crystal X-ray diffraction analysis as illustrated in Fig. 4. It confirms the characterization of $\mathbf{3}$ as an octahedral diplatinum(IV) complex formed by oxidative addition of MeI to complex $\mathbf{1}$. The coordination geometry around each platinum atom is octahedral with the Me group, the nitrogen atom and the ortho $\mathrm{C}$ of the ppy ligand, iodide and one $\mathrm{P}$ atom of the dppac. The three carbon atoms have fac geometry. The bond distances between platinum and carbon atom is 2.089(14) $\AA$ for Pt1-C52. This value is considerably shorter than Pt1-C14 bond in the complex 2 (here the bond length is 2.069(6) $\AA$ ), indicating the conversion of $\mathrm{Pt}(\mathrm{II})$ to $\mathrm{Pt}(\mathrm{IV})$ product upon oxidative addition reaction. The iodide atom is located trans to the $C$ atom of the ppy

(g)

(f)

(e)

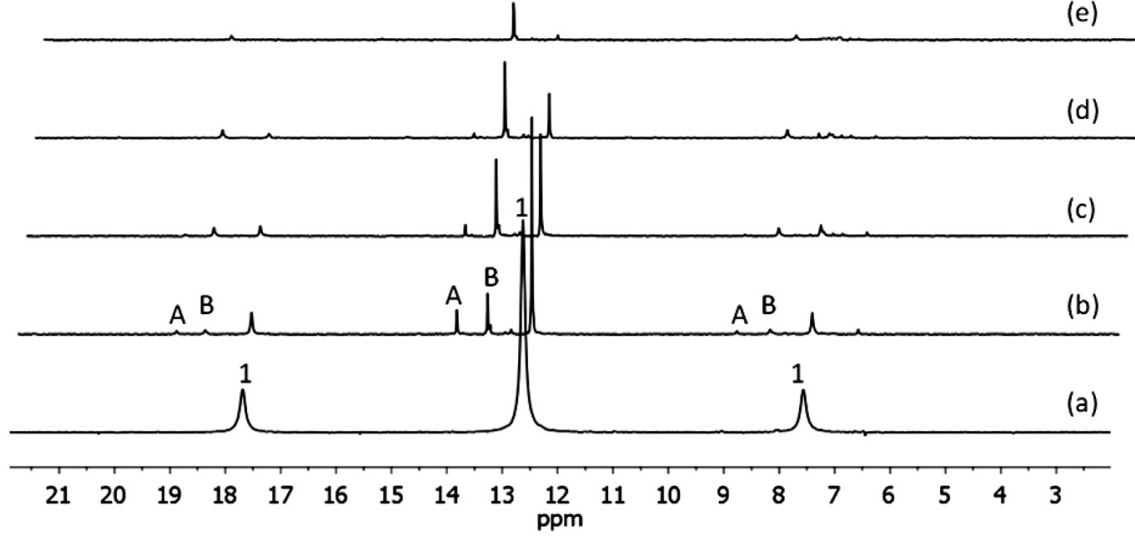

(d)

)

(a)

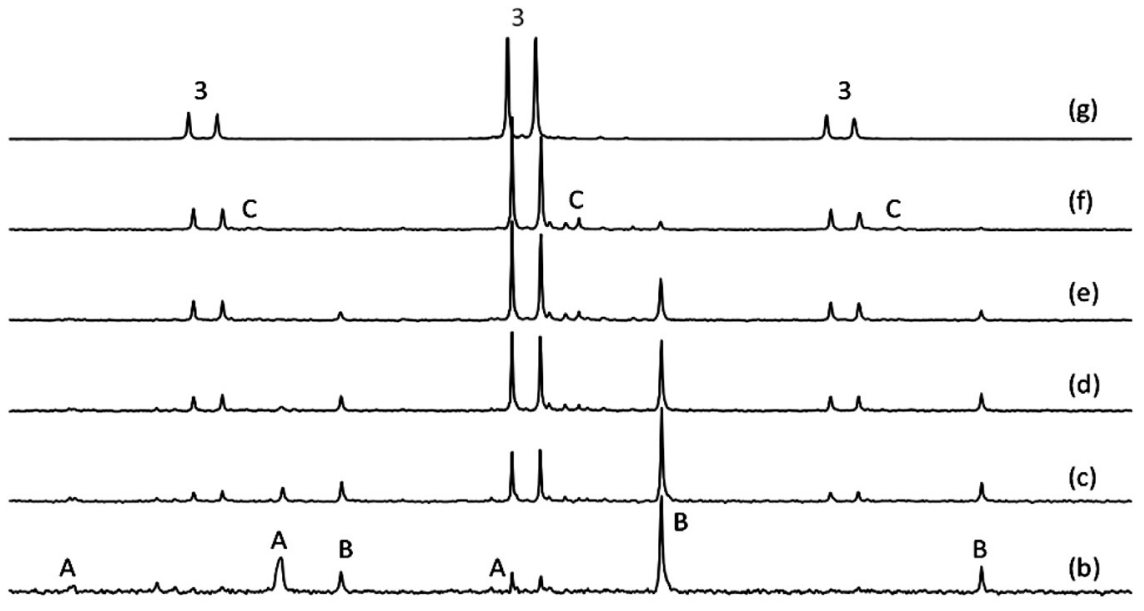

(a)

\begin{tabular}{llllllll}
\hline-20.5 & -21.5 & -22.5 & -23.5 & $\begin{array}{l}-24.5 \\
\mathrm{ppm}\end{array}$ & -25.5 & -26.5 & -27.5
\end{tabular}

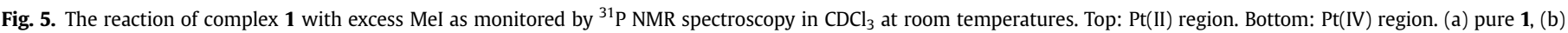

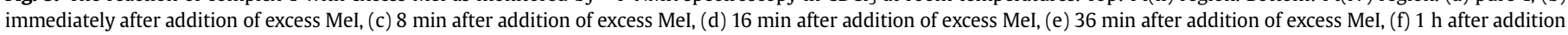
of excess MeI and (g) 100 min after addition of excess MeI. The peak assignments are shown. 
ligand. The bond length of Pt1-C50 (trans to P1) and Pt1-C52 (trans to N1) are 2.102(6) and 2.089(14), respectively. The trend is in agreement with the observed ${ }^{2} J_{\mathrm{PtH}}$ values in ${ }^{1} \mathrm{H}$ NMR of complex $\mathbf{3}$, showing lower trans influence of $\mathrm{N}$ atom as compared with that of $\mathrm{P}$ atom. The two methyl groups are cis disposed to one another (C50Pt1-C52 92.0(4) ${ }^{\circ}$ ), indicating that the angles around the Pt center are rather close to the ideal angle of $90^{\circ}$. The aromatic $\mathrm{N}$ atom is coordinated to platinum center, which is in accord to the usual preference of the ppy ligand to form cyclometalated complexes, and is positioned trans to a Me group. The Pt1-P1 distance of 2.3886(14) $\AA$ in complex 3 is significantly longer than the Pt1-P1 distance of 2.2672(17) $\AA$ in complex 2, consistent with the oxidation states of +4 and +2 for Pt atoms in complexes 3 and 2, respectively. To the best of our knowledge this is the first X-ray structural determination of a diplatinum(IV) complex having dppac as bridging ligand.

\subsection{Kinetic and mechanism of the reaction of complexes $\mathbf{1}$ and $\mathbf{2}$ with MeI}

On the basis of the NMR and UV-vis spectroscopic studies, described below, a mechanism for reaction of complexes $\mathbf{1}$ and $\mathbf{2}$ with MeI is suggested as shown in Scheme 3.

\subsubsection{Monitoring the reaction of complex 1 with $\mathrm{MeI}$ by ${ }^{31} \mathrm{P} N \mathrm{NR}$ spectroscopy}

To investigate the details of mechanism of addition of MeI to diplatinum(II) complexes containing dppac as spacer ligand, the reaction of complex $\left[\mathrm{Pt}_{2} \mathrm{Me}_{2}(\mathrm{ppy})_{2}(\mu\right.$-dppac)], 1, with excess $\mathrm{MeI}$ in $\mathrm{CDCl}_{3}$ was monitored by ${ }^{31} \mathrm{P}$ NMR spectroscopy at room temperature. The spectra are shown in Fig. 5. Based on the results obtained from ${ }^{31} \mathrm{P}$ NMR spectroscopy (and UV-vis spectroscopy, see next section), the complexes and intermediates suggested for the reaction sequence, described in Scheme 3, were assigned. The complexes $\mathbf{1}$ and $\mathbf{3}$ are characterized as described in the main text and Experimental section. Therefore the characteristic ${ }^{31} \mathrm{P}$ NMR data for these complexes were used to indicate the complexes in the reaction sequence. Immediately after the addition of MeI at room temperature, apart from complex 1, two $\mathrm{Pt}(\mathrm{II})-\mathrm{Pt}(\mathrm{IV})$ species assigned as intermediates $\mathbf{A}$ and $\mathbf{B}$, were detected. For intermediate A, two singlet signals, one at $\delta 14.0$ (with ${ }^{1} J_{\mathrm{PtP}}=2047 \mathrm{~Hz}$ close to that of the $\mathrm{Pt}(\mathrm{II})-\mathrm{Pt}(\mathrm{II})$ starting complex 1) and another one at $\delta-24.0$ with ${ }^{1} \mathrm{JPtP}=639 \mathrm{~Hz}$, were observed. The latter value is typical for Pt(IV)-P coupling, but is higher than the corresponding value found for Pt(IV)-Pt(IV) complex 3 (with ${ }^{1} J_{\mathrm{PtP}}=628 \mathrm{~Hz}$ ); this

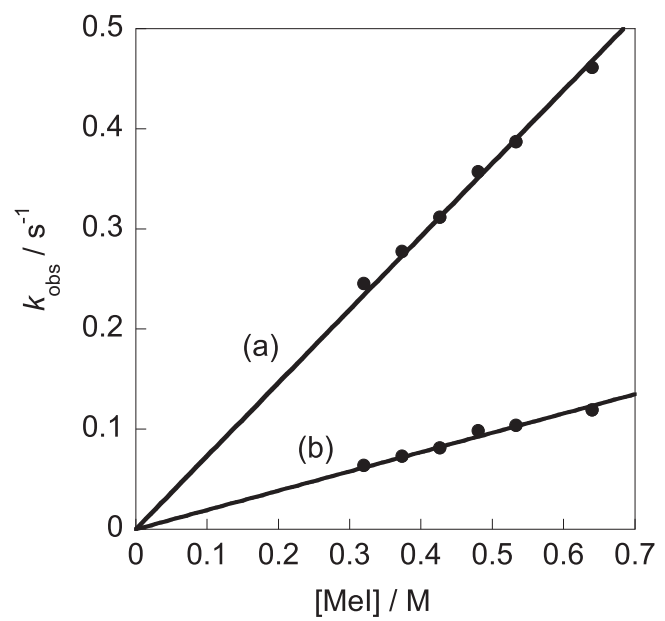

Fig. 7. Plots of first-order rate constants [(a) first step, $k_{\mathrm{obs}} / \mathrm{s}^{-1}$, and (b) second step, $k_{\mathrm{obs}}^{\prime} / \mathrm{s}^{-1}$ ] for the reaction of complex 1 with MeI at $30{ }^{\circ} \mathrm{C}$ versus [MeI] in $\mathrm{CHCl}_{3}$.

is probably due to higher trans influence of Me as compared to that of the ppy- $C$ ligand. For intermediate $\mathbf{B}$, two singlet signals, one at $\delta 11.4$ (with ${ }^{1} J_{\mathrm{PtP}}=1838 \mathrm{~Hz}$, located in the $\mathrm{Pt}(\mathrm{II})$ region) and another one at $\delta-26.9$, located in the Pt(IV) region with ${ }^{1} J_{\mathrm{PtP}}=988 \mathrm{~Hz}$, were observed. As the time was passing on, the signals due to the starting material 1, and intermediates $\mathbf{A}$ and $\mathbf{B}$ were disappearing while those due to the intermediate $\mathbf{C}$ and final product $\mathbf{3}$ were growing. For the intermediate $\mathbf{C}$, two signals in the Pt(IV) regions with expected ${ }^{1} J_{\mathrm{PtP}}$ values (one signal at $\delta-24.2$, with ${ }^{1} J_{\mathrm{PtP}}=971 \mathrm{~Hz}$, another signal at $\delta-24.3$, with ${ }^{1} \mathrm{JPtP}=980 \mathrm{~Hz}$ ) were observed. After $100 \mathrm{~min}$, all the signals were completely disappeared and the final $\mathrm{Pt}(\mathrm{IV})-\mathrm{Pt}(\mathrm{IV})$ product 7 was purely obtained.

\subsubsection{Kinetic studies using UV-vis spectroscopy}

The kinetics of oxidative addition of $\mathrm{MeI}$ in $\mathrm{CHCl}_{3}$ to binuclear complexes 1 and $\mathbf{2}$ was studied by using UV-vis spectroscopy. In each case, an excess of MeI was used and disappearance of the MLCT band was followed to monitor the reaction. The change in the spectrum during a typical run is shown in Fig. 6. The absorbancetime curves monitored at $360 \mathrm{~nm}$ for the reaction of complex $\mathbf{1}$ (or $400 \mathrm{~nm}$ for complex 2) with $\mathrm{MeI}$ in $\mathrm{CHCl}_{3}$ solution were obtained in the presence of large excesses of MeI, such that its concentration remained effectively constant in each experiment. The kinetic data were in accord with the occurrence of two sequential first-order
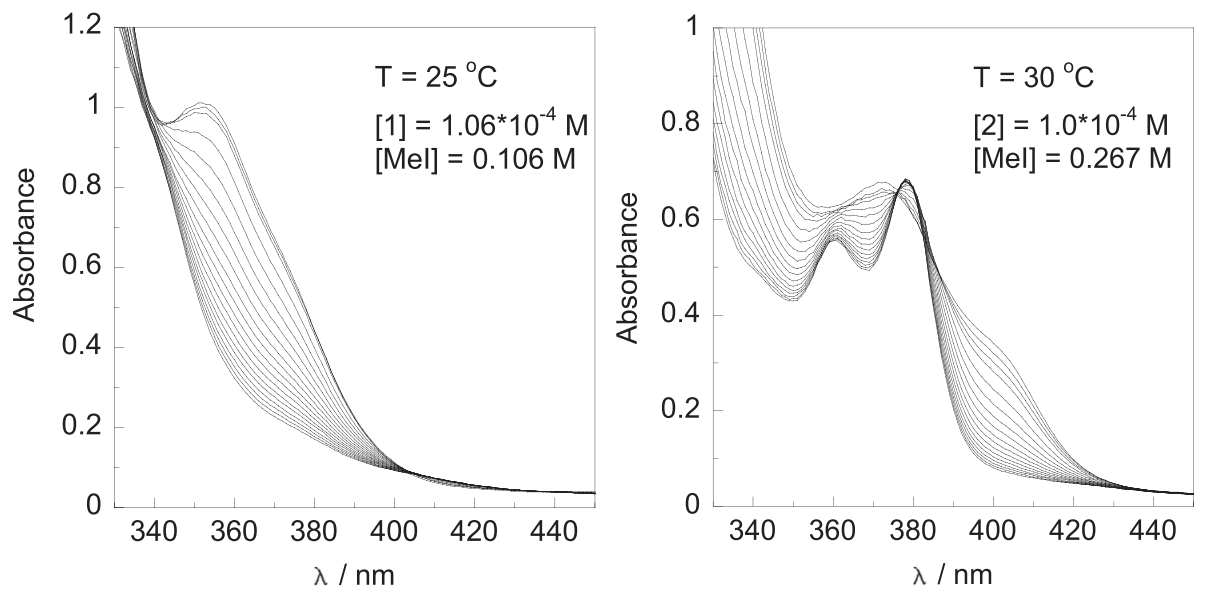

Fig. 6. Changes in the UV-vis spectrum during the reaction of complexes $\mathbf{1}$ (left) and $\mathbf{2}$ (right) with $\mathrm{MeI}_{\text {in }} \mathrm{CHCl}_{3}$; successive spectra were recorded at intervals of $30 \mathrm{~s}$. 
Table 2

Rate constants $^{\mathrm{a}}$ and activation parameters ${ }^{\mathrm{b}}$ for reaction of complexes $\mathbf{1}$ and $\mathbf{2}$ with $\mathrm{MeI}$ in $\mathrm{CHCl}_{3}$.

\begin{tabular}{|c|c|c|c|c|c|c|c|c|}
\hline & \multicolumn{8}{|c|}{ Rate constants at different temperatures } \\
\hline & $10^{\circ} \mathrm{C}$ & $20^{\circ} \mathrm{C}$ & $25^{\circ} \mathrm{C}$ & $30{ }^{\circ} \mathrm{C}$ & $35^{\circ} \mathrm{C}$ & $40^{\circ} \mathrm{C}$ & $\Delta H^{\ddagger} / \mathrm{kJ} \mathrm{mol}{ }^{-1}$ & $\Delta S^{\ddagger} / \mathrm{J} \mathrm{K}^{-1} \mathrm{~mol}^{-1}$ \\
\hline \multicolumn{9}{|l|}{ Complex 1} \\
\hline $10^{2} k_{2} /\left(\mathrm{L} \mathrm{mol}^{-1} \mathrm{~s}^{-1}\right)$ & 0.36 & 0.70 & 0.89 & 1.22 & 1.61 & 2.24 & $41.9 \pm 0.9$ & $-143 \pm 3$ \\
\hline $10^{2} k_{2}^{\prime} /\left(\mathrm{L} \mathrm{mol}^{-1} \mathrm{~s}^{-1}\right)$ & 0.10 & 0.19 & 0.24 & 0.32 & 0.43 & 0.56 & $38.9 \pm 0.8$ & $-164 \pm 3$ \\
\hline \multicolumn{9}{|l|}{ Complex 2} \\
\hline $10^{2} k_{2} /\left(\mathrm{L} \mathrm{mol}^{-1} \mathrm{~s}^{-1}\right)$ & 0.29 & 0.59 & 0.67 & 1.00 & 1.24 & 1.45 & $37.4 \pm 2.2$ & $-160 \pm 8$ \\
\hline $10^{2} k^{\prime}{ }_{2} /\left(\mathrm{L} \mathrm{mol}^{-1} \mathrm{~s}^{-1}\right)$ & 0.09 & 0.15 & 0.18 & 0.24 & 0.28 & 0.37 & $31.1 \pm 1.1$ & $-192 \pm 4$ \\
\hline
\end{tabular}

a Estimated error in $k$ values are $\pm 5 \%$.

b Obtained from the Eyring equation.

reactions. Thus, the pseudo-first-order rate constants, $k_{\mathrm{obs}(1)}$ and $k_{\mathrm{obs}(2)}$, for the two steps of the reaction were evaluated by nonlinear least-square fitting of the absorbance-time profiles to the biphasic first order equation (Eq. (1) and Fig. 1S).

$\mathrm{Abs}_{\mathrm{t}}=\alpha\left[\exp \left(-k_{\mathrm{obs}(1)} \mathrm{t}\right)\right]+\beta\left[\exp \left(-k_{\mathrm{obs}(2)} \mathrm{t}\right)\right]+\mathrm{Abs}_{\infty}$

Both of the pseudo-first-order rate constants $k_{\mathrm{obs}(1)}$ and $k_{\mathrm{obs}(2)}$ show a variation with [MeI] that is linear with no intercepts (Fig. 7), showing a first-order dependence of the rate on the concentration of MeI in each step. Least-squares analysis gives the second-order rate constants ( $k_{2}$ for the first step and $k_{2}^{\prime}$ for the second step) and the results are given in Table 2 . The findings are consistent with the two-step sequence indicated in the last section based on the ${ }^{31} \mathrm{P}$ NMR data (see Fig. 5) for the reaction of complex 1 with MeI. Therefore, each step of the reaction (see Scheme 3) obeys a simple second-order rate law (Eq. (2) for step 1 and Eq. (3) for step 2); note that $k_{2}>k_{2}^{\prime}$ and the reproducibility of the data were remarkable $( \pm 4 \%)$. The same method was used at other temperatures and activation parameters were obtained from the Eyring equation (see Eq. (4) and Fig. 2S). The data are shown in Table 2.

$-\mathrm{d}[\mathbf{1}] / \mathrm{d} t=k_{2}[\mathbf{1}][\mathrm{Me}]$

$-\mathrm{d}[\mathbf{B}] / \mathrm{d} t=k_{2}^{\prime}[\mathbf{B}][\mathrm{MeI}]-k_{2}[\mathbf{1}][\mathrm{MeI}]$

$\ln \left(\frac{k}{T}\right)=\ln \left(\frac{k_{B}}{h}\right)+\frac{\Delta S^{\ddagger}}{R}-\frac{\Delta H^{\ddagger}}{R T} k=k_{2}$ or $k_{2}^{\prime}$

The values of the entropy of activation were large and negative for both steps, which are in favor of a classical $\mathrm{S}_{\mathrm{N}} 2$ type mechanism. Based on these NMR and kinetic data, we suggest that as shown in Scheme 3, at the first step MeI attacks (via an electrophilic addition) on one of the electron rich Pt(II) centers of dimer complex 1 with an $\mathrm{S}_{\mathrm{N}} 2$ type mechanism with the rate constant $k_{2}$ and the mix valence $\mathrm{Pt}(\mathrm{II})-\mathrm{Pt}(\mathrm{IV})$ binuclear intermediate $\mathbf{A}$ is formed. The intermediate A would then quickly performs a facile trans to cis isomerization of the $\mathrm{Pt}(\mathrm{IV})$ center having Me and I in trans disposition to form the intermediate $\mathbf{B}$. Intermediate $\mathbf{B}$ was then reacted with $\mathrm{MeI}$ in the second step again by an $\mathrm{S}_{\mathrm{N}} 2$ type mechanism, with the rate constant $k_{2}^{\prime}$ which is nearly 4 times smaller than the corresponding value for the rate constant of first step ( $k_{2}$, see Table 2$)$ to form intermediate $\mathbf{C}$ (Scheme 3). Then, a rapid trans-cis isomerization of the resulting $\mathrm{Pt}(\mathrm{IV})$ center was occurred to form the final product 3.

As is clear from Table 2, in the two-step oxidative addition reactions studied in this work based on the qualitative ${ }^{31} \mathrm{P}$ NMR investigations and UV-vis calculation (see Supporting information for rate constants assignment using the Espenson's approach [68]), the step 2 appears to be slower than the step 1 . In step 1, MeI attacks the $\mathrm{Pt}(\mathrm{II})$ center of a $\mathrm{Pt}(\mathrm{II})-\mathrm{Pt}(\mathrm{II})$ complex, 1, while in step 2, MeI reacts with the $\mathrm{Pt}(\mathrm{II})$ center of a $\mathrm{Pt}(\mathrm{II})-\mathrm{Pt}(\mathrm{IV})$ species (complex B). As such the reaction should be slower in the second step since in contrast to complex $\mathbf{1}$, in species $\mathbf{2}$, the adjacent Pt(IV) moiety reduces the nucleophilicity of the Pt(II) center through the bridging biphosphine group, dppac.

\subsection{Effect of $\mathrm{CN}$ ligand on the rate of oxidative addition reaction}

As is clear from Table 2, the reaction rates of complex [Pt $\mathrm{Pe}_{2}$ (bhq) $)_{2}\left(\mu\right.$-dppac)], 2, with $\mathrm{MeI}$ in $\mathrm{CHCl}_{3}$ at different temperatures for both steps, are at least 1.2-1.3 times slower than the corresponding reaction of complex $\left[\mathrm{Pt}_{2} \mathrm{Me}_{2}(\mathrm{ppy})_{2}(\mu\right.$-dppac)], 1. For example, in step 1 , MeI at $25^{\circ} \mathrm{C}$ reacted nearly 1.3 times faster with $\left[\mathrm{Pt}_{2} \mathrm{Me}_{2}(\text { ppy })_{2}(\mu\right.$-dppac $\left.)\right]\left(k_{2}=5.36 \times 10^{-1} \mathrm{Lmol}^{-1} \mathrm{~s}^{-1}\right)$ than with 2 $\left(k_{2}=4.01 \times 10^{-1} \mathrm{Lmol}^{-1} \mathrm{~s}^{-1}\right)$. This confirms the stronger donor ability of the ppy ligand as compared to that of the bhq ligand and shows that the platinum center in the ppy complex $\mathbf{1}$ is more electron rich than the platinum center in complex $\mathbf{2}$ toward electrophilic attacks. This is consistent with the trends found for ${ }^{1} \mathrm{JtP}$ values in the ${ }^{31} \mathrm{P}$ NMR spectra of the analogous complexes 1 $(2049 \mathrm{~Hz})$ and $2(2102 \mathrm{~Hz})$. Therefore it may be concluded that the trans influence of metalated $C$ atom of ppy ligand is greater than that of bhq ligand [57,69].

\section{Conclusions}

Two new binuclear complexes, $\left[\mathrm{Pt}_{2} \mathrm{Me}_{2}(\mathrm{CN})_{2}(\mu\right.$-dppac)], in which $\mathrm{CN}$ = deprotonated 2-phenylpyridine (1) or benzo $\{\mathrm{h}\}$ quinoline (2) and dppac = bis(diphenylphosphino)acetylene, were synthesized. The related two-step reactions of complexes $\mathbf{1}$ and $\mathbf{2}$ with MeI were investigated by UV-vis spectrophotometry; the reaction of complex 1 with MeI was also monitored by ${ }^{31} \mathrm{P}$ NMR spectroscopy. On the basis of the results, both steps of MeI oxidative addition proceed by the classical $\mathrm{S}_{\mathrm{N}} 2$ type mechanism [70,71], as shown in Scheme 3, with large negative $\Delta S^{\ddagger}$ values. In the first step, the electron rich platinum center of the Pt(II)-Pt(II) starting complex 1 attacks the methyl carbon of MeI to form the intermediate $\mathbf{B}$ which is suggested to be a $\mathrm{Pt}(\mathrm{II})-\mathrm{Pt}(\mathrm{IV})$ complex. The rate of the reaction of the platinum(II) center in complex $\mathbf{B}$ with MeI was considerably slower (by a factor of 4 ) than that for the platinum(II) center in the starting complex $\mathbf{1}$, which is consistent with a significant electronic effect transmitted through the dppac bridging ligand. The $\mathrm{Pt}-\mathrm{P}$ bond length for $\mathrm{P}$ atom trans to the $\mathrm{C}$ atom of ppy ligand is rather longer than that of the $P$ atom trans to the $C$ atom of bhq ligand. The difference, although modest, indicates that ppy ligand probably exerts a higher trans influence than the bhq ligand. This is in agreement with the values of ${ }^{1} J_{\mathrm{PtP}}$ (observed in the ${ }^{31} \mathrm{P}$ 
NMR spectra) and rates of MeI oxidative addition of the related complexes.

\section{Acknowledgments}

This work has been supported by Shiraz University and the Iran National Science Foundation (Grant No. 90005392). We are grateful to M. Golbon Haghighi for valuable suggestions and Dr. H. R. Shahsavari for helpful assistance. We thank University of Isfahan, for the diffractometer facility.

\section{Appendix A. Supplementary material}

CCDC 928600 and 930544 contain the supplementary crystallographic data for this paper. These data can be obtained free of charge from The Cambridge Crystallographic Data Centre via www. ccdc.cam.ac.uk/data_request/cif.

\section{Appendix B. Supplementary data}

Supplementary data related to this article can be found at http:// dx.doi.org/10.1016/j.jorganchem.2013.07.032.

\section{References}

[1] S.N. Semenov, O. Blacque, T. Fox, K. Venkatesan, H. Berke, J. Am. Chem. Soc 132 (2010) 3115-3127.

[2] K.-J. Wei, J. Ni, Y. Liu, Inorg. Chem. 49 (2010) 1834-1848.

[3] B. Xi, I.P.-C. Liu, G.-L. Xu, M.M. Choudhuri, M.C. DeRosa, R.J. Crutchley, T. Ren J. Am. Chem. Soc. 133 (2011) 15094-15104.

[4] J.L. Chen, L.Y. Zhang, Z.N. Chen, L.B. Gao, M. Abe, Y. Sasaki, Inorg. Chem. 43 (2004) 1481-1490.

[5] K.D. Demadis, C.M. Hartshorn, T.J. Meyer, Chem. Rev. 101 (2001) 2655-2686.

[6] F.A. Cotton, C. Lin, C.A. Murillo, Acc. Chem. Res. 34 (2001) 759-771.

[7] F. Barigelletti, L. Flamigni, Chem. Soc. Rev. 29 (2000) 1-12.

[8] W. Kaim, A. Klein, M. Glockle, Acc. Chem. Res. 33 (2000) 755-763.

[9] R.L. Carroll, C.B. Gorman, Angew. Chem. Int. Ed. 41 (2002) 4378-4400.

[10] P.J. Steel, Acc. Chem. Res. 38 (2005) 243-250.

[11] Y.C. Liu, C.I. Li, W.Y. Yeh, G.H. Lee, S.M. Peng, Inorg. Chim. Acta 359 (2006) 2361-2368

[12] M. Ruben, J. Rojo, F.J. Romero-Salguero, L.H. Uppadine, J.M. Lehn, Angew Chem. Int. Ed. 43 (2004) 3644-3662.

[13] Y. Hoshino, S. Higuchi, J. Fiedler, C.Y. Su, A. Knodler, B. Schwederski, B. Sarkar, H. Hartmann, W. Kaim, Angew. Chem. Int. Ed. 42 (2003) 674-677.

[14] P.J. Mosher, G.P.A. Yap, R.J. Crutchley, Inorg. Chem. 40 (2001) 1189-1195.

[15] R. Dembinski, T. Bartik, B. Bartik, M. Jaeger, J. Gladysz, J. Am. Chem. Soc. 122 (2000) 810-822.

[16] F. Paul, W.E. Meyer, L. Toupet, H. Jiao, J.A. Gladysz, C. Lapinte, J. Am. Chem. Soc. 122 (2000) 9405-9414.

17] T. Ren, G. Zou, J.C. Alvarez, Chem. Commun. (2000) 1197-1198.

[18] K.T. Wong, J.M. Lehn, S.M. Peng, G.H. Lee, Chem. Commun. (2000) 2259-2260

[19] J. Bear, B. Han, Z. Wu, E. Van Caemelbecke, K. Kadish, Inorg. Chem. 40 (2001) 2275-2281.

[20] F.A. Cotton, J.P. Donahue, C.A. Murillo, J. Am. Chem. Soc. 125 (2003) 54365450

[21] S. Bhargava, K. Kitadai, T. Masashi, D.W. Drumm, S.P. Russo, V.W.-W. Yam, T.K.-M. Lee, J. Wagler, N. Mirzadeh, Dalton Trans, 41 (2012) 4789-4798.

[22] A. Fazal, B.E. Ali, L. Ouahab, M. Fettouhi, Polyhedron 49 (2013) 7-11.

[23] M.A. Bennett, J. Castro, A.J. Edwards, M.R. Kopp, E. Wenger, A.C. Willis Organometallics 20 (2001) 980-989.

[24] K.S. Shin, K.I. Son, J.I. Kim, C.S. Hong, M. Suh, D.Y. Noh, Dalton Trans. (2009) 1767-1775

[25] A.K. Powell, M.J. Went, J. Chem. Soc. Dalton Trans. (1992) 439-445.

[26] J.-C. Daran, E. Cabrera, M.I. Bruce, M.L. Williams, J. Organomet. Chem. 319 (1987) 239-246.

[27] G. Hogarth, T. Norman, Polyhedron 15 (1996) 2859-2867.
[28] D. Xu, H.J. Murfee, W.E. van der Veer, B. Hong, J. Organomet. Chem. 596 (2000) $53-63$.

[29] V.K. Jain, L. Jain, Coord. Chem. Rev. 249 (2005) 3075-3197.

[30] K.S. Shin, D.Y. Noh, Bull. Korean Chem. Soc. 25 (2004) 130-132.

[31] L.R. Falvello, J. Forniés, J. Gómez, E. Lalinde, A. Martín, F. Martínez, M.T. Moreno, J. Chem. Soc. Dalton Trans. (2001) 2132-2140.

[32] J.R. Galsworthy, C.E. Housecroft, A.L. Rheingold, J. Chem. Soc. Dalton Trans. (1996) 2917-2922.

[33] S.L. James, E. Lozano, M. Nieuwenhuyzen, Chem. Commun. (2000) 617-618.

[34] O. Orama, J. Organomet. Chem. 314 (1986) 273-279.

[35] E. Louattani, J. Suades, K. Urtiaga, M. Arriortua, X. Solans, Organometallics 15 (1996) 468-471.

[36] G. Hogarth, T. Norman, J. Chem. Soc. Dalton Trans. (1996) 1077-1085.

[37] M. Albrecht, R.A. Gossage, U. Frey, A.W. Ehlers, E.J. Baerends, A.E. Merbach, G. Van Koten, Inorg. Chem. 40 (2001) 850-855.

[38] M. Hissler, J.E. McGarrah, W.B. Connick, D.K. Geiger, S.D. Cummings, R. Eisenberg, Coord. Chem. Rev. 208 (2000) 115-137.

[39] S.W. Lai, T.C. Cheung, M.C.W. Chan, K.K. Cheung, S.M. Peng, C.M. Che, Inorg. Chem. 39 (2000) 255-262.

[40] H. Jude, J.A.K. Bauer, W.B. Connick, Inorg. Chem. 44 (2005) 1211-1220.

[41] H. Yersin, Highly Efficient OLEDs with Phosphorescent Materials, Wiley-VCH, 2008.

[42] R.C. Evans, P. Douglas, C.J. Winscom, Coord. Chem. Rev. 250 (2006) 20932126.

[43] D.N. Kozhevnikov, V.N. Kozhevnikov, M.M. Ustinova, A. Santoro, D.W. Bruce, B. Koenig, R. Czerwieniec, T. Fischer, M. Zabel, H. Yersin, Inorg. Chem. 48 (2009) 4179-4189.

[44] J. Schneider, P. Du, X. Wang, W.W. Brennessel, R. Eisenberg, Inorg. Chem. 48 (2009) 1498-1506.

[45] A.F. Rausch, U.V. Monkowius, M. Zabel, H. Yersin, Inorg. Chem. 49 (2010) 7818-7825.

[46] M. Ghedini, T. Pugliese, M. La Deda, N. Godbert, I. Aiello, M. Amati, S. Belviso, F. Lelj, G. Accorsi, F. Barigelletti, Dalton Trans. (2008) 4303-4318.

[47] T. Calvet, M. Crespo, M. Font-Bardia, K. Gómez, G. González, M. Martínez, Organometallics 28 (2009) 5096-5106.

[48] C.K. Koo, K.L. Wong, K.C. Lau, W.Y. Wong, M.H.W. Lam, Chem. Eur. J. 15 (2009) 7689-7697.

[49] A.A. Rachford, F.N. Castellano, Inorg. Chem. 48 (2009) 10865-10867.

[50] S.K. Yen, D.J. Young, H.V. Huynh, L.L. Koh, T.S.A. Hor, Chem. Commun. (2009) 6831-6833.

[51] M. Lopez-Torres, A. Fernandez, J.J. Fernandez, A. Suarez, S. Castro-Juiz, J.M. Vila, M.T. Pereira, Organometallics 20 (2001) 1350-1353.

[52] P.A. Chase, R.J.M. Gebbink, G. van Koten, J. Organomet. Chem. 689 (2004) 4016-4054

[53] H.P. Dijkstra, C.A. Kruithof, N. Ronde, R. van de Coevering, D.J. Ramón, D. Vogt, G.P.M. van Klink, G. van Koten, J. Org. Chem. 68 (2003) 675-685.

[54] M.G. Haghighi, M. Rashidi, S.M. Nabavizadeh, S. Jamali, R.J. Puddephatt, Dalton Trans. 39 (2010) 11396-11402.

[55] S. Jamali, Z. Mazloomi, S.M. Nabavizadeh, D. Milic, R. Kia, M. Rashidi, Inorg. Chem. 49 (2010) 2721-2726.

[56] S.M. Nabavizadeh, M.G. Haghighi, A.R. Esmaeilbeig, F. Raoof, Z. Mandegani, S. Jamali, M. Rashidi, R.J. Puddephatt, Organometallics 29 (2010) 4893-4899.

[57] S.M. Nabavizadeh, H. Amini, H.R. Shahsavari, M. Namdar, M. Rashidi, R. Kia, B. Hemmateenejad, M. Nekoeinia, A. Ariafard, F.N. Hosseini, Organometallics 30 (2011) 1466-1477.

[58] X-AREA Stoe \& Cie, Version 1.52: Program for the Acquisition and Data Analysis, Stoe \& Cie GmbH, Darmstadt, Germany, 2009.

[59] R.H. Blessing, Acta Crystallogr. Sect. A Found Crystallogr. 51 (1995) 33-38.

[60] A.L. Spek, Acta Crystallogr. Sect. D Biol. Crystallogr. 65 (2009) 148-155.

[61] G.M. Sheldrick, Acta Crystallogr. Sect. A Found Crystallogr. 64 (2008) 112

[62] J.D. Scott, R.J. Puddephatt, Organometallics 2 (1983) 1643-1648.

[63] P.K. Monaghan, R.J. Puddephatt, Organometallics 3 (1984) 444-449.

[64] S. Jamali, S.M. Nabavizadeh, M. Rashidi, Inorg. Chem. 44 (2005) 8594-8601.

[65] S.J. Hoseini, S.M. Nabavizadeh, S. Jamali, M. Rashidi, Eur. J. Inorg. Chem. 2008 (2008) 5099-5105.

[66] S. Jamali, S.M. Nabavizadeh, M. Rashidi, Inorg. Chem. 47 (2008) 5441-5452.

[67] T.G. Appleton, M.A. Bennett, I.B. Tomkins, J. Chem. Soc. Dalton Trans. (1976) 439-446.

[68] M. Shimura, J.H. Espenson, Inorg. Chem. 23 (1984) 4069-4071.

[69] S.M. Nabavizadeh, M.D. Aseman, B. Ghaffari, M. Rashidi, F.N. Hosseini, G. Azimi, J. Organomet. Chem. 715 (2012) 73-81.

[70] M. Werner, C. Bruhn, D. Steinborn, Trans. Met. Chem. 34 (2009) 61-74.

[71] T. Calvet, M. Crespo, M. Font-Bardía, S. Jansat, M. Martínez, Organometallics 31 (2012) 4367-4373 